\title{
European Accounting and
}

Management Review

\section{Volume 5, Issue 2, May 2019}

ISSN (online): 2385-3921

Published on

https://eamr-accid.eu 


\section{European Accounting and Management Review}

\section{Volume 5, Issue 2, May 2019}

\section{INDEX}

Seasonality, infrastructures and Economic Growth in Touristic Islands 1 Juan Pedro Aznar, Josep Maria Sayeras Maspera and Jordi Vives

Turnaround Types, Stages, Strategies, and Tactics: Putting Things in Order Sharon Gotteiner, Marta Mas-Machuca and Frederic Marimon

A Simplified Balanced 'Balanced Scorecard'

Ivan Malbasic and Frederic Marimon 


\title{
EAMR
}

\section{EUROPEAN ACCOUNTING AND MANAGEMENT REVIEW}

VOLUME 5, ISSUE 2, ARTICLE 1, 1-11, MAY 2019

\section{Seasonality, infrastructures and Economic Growth in Touristic Islands}

\author{
Juan Pedro Aznar \\ ESADE Business and Law School, Ramon Llull University \\ Josep Maria Sayeras Maspera \\ ESADE Business and Law School, Ramon Llull University \\ Jordi Vives \\ ESADE Business and Law School, Ramon Llull University
}

Received February 28, 2019; accepted April 5, 2019.

\begin{abstract}
Tourism is the main economic activity in some small islands that have became very dependent on this activity. Sun and beach destinations are characterized by high levels of seasonality, with consequences on unemployment, economic activity diversification and GDP per capita. This paper analyzes the empirical evidence from the Balearic island of Mallorca, one of the most important touristic destinations in Spain. This research has analyzed the existence of correlation between seasonality and unemployment, GDP per capita, housing prices, the paper also examines the importance of location and infrastructure. The variable with a highest explanatory capacity in terms of GDP per capita is the distance to the airport. National and regional governments must consider the importance of infrastructures and the role seasonality plays in economic growth and economic activity diversification; the understanding of these relations will help to develop the most adequate public policies.
\end{abstract}

\section{KEYWORDS}

Seasonality, infrastructures, location, islands' tourism. 


\section{Introduction}

Tourism and related activities is one the industries with a higher impact in terms of economic activity, representing in 2016 around 10.2\% of the World Gross Domestic Product and $10 \%$ of total employment worldwide (World Travel and Tourism Council, 2016). Economist have analyzed the relation between tourism and economic growth either from a theoretical perspective (Hazari and Sgro, 2004) or empirical (Dritsakis, 2004); supporting the idea that tourism activity can lead to a higher economic growth. However, tourism activity can create some negative impact, with the idea of a situation of Dutch Disease as one of the most important ones (Nowak and Sahli, 2007; Capo et al. 2007). In a situation of Dutch Disease the increasing demand on tourism can lead to a situation in which the investment directed to the tourism industries leads to a crowding out effect for investment in alternative industries, generating as a final effect a loss in the net welfare. This situation has been examined mainly for small islands in which tourism ranks as top economic activity. In some islands the importance of travel and tourism expenditure as a percentage of the GDP makes clear the high level of dependency on this industry; $96.5 \%$ in Maldives, $62.1 \%$ in Seychelles, $43.2 \%$ in Cabo Verde or $27.7 \%$ in Malta (World Travel and Tourism Council, 2016).

Many touristic small islands can be considered sun and beach destinations, in which tourist are attracted by the weather and the beauty of the natural landscape. This tourism is very dependent on climate conditions, making the economic activity highly correlated with the season (Donatos and Zairis, 1991; Baum and Hagen, 1999; Conell et al, 2015). One of the main objectives of many regional and local governments has been to extend the duration of the peak demand season and to reduce the level of seasonality, but this is a difficult task affected by many factors out of the control of policy makers.

In the context of the importance of tourism Spain is a clear example of how tourism has mixed effects. The financial crisis that started in 2008 was a extremely difficult period for the Spanish economy with the level of unemployment rocketing from less than $10 \%$ to more than $25 \%$ in 2013.Tourism is one of the activities that has helped to create employment and has shown as steadily and consistent growth in the last decade. International tourist arrivals have reached a maximum of 75.3 million international tourist arrivals in 2016 compared with 58.5 millions of international tourist arrivals in 2006 
(Spanish Statistical Office INE, 2016). But there is also an open debate about negative effects that tourism can have in terms of public space congestion, effects on housing prices or the excessive dependence of just one economic sector. Spain has different touristic destinations but many of them can be considered sun a beach touristic destination, with the Balearic Island and Canary Islands leading the positions of this kind of tourism activity. Table 1 shows the evolution for the island of Mallorca (Spanish Statistic Office INE, 2016), the biggest one of the Balearic Islands.

\begin{tabular}{|c|c|c|}
\hline Year & $\begin{array}{c}\text { International tourist } \\
\text { arrivals }\end{array}$ & $\begin{array}{c}\text { Number of beds } \\
\text { available }\end{array}$ \\
\hline 2009 & $9,024,039$ & 149,495 \\
\hline 2010 & $9,201,824$ & 151,014 \\
\hline 2011 & $10,111,333$ & 150,701 \\
\hline 2012 & $10,365,710$ & 150,336 \\
\hline 2013 & $11,057,460$ & 152,071 \\
\hline 2014 & $11,348,260$ & 154,251 \\
\hline 2015 & $11,649,470$ & 152,973 \\
\hline
\end{tabular}

Table 1. Interantional tourist arrivals to Mallorca.

As the rest of the Balearic and Canary islands, Mallorca shows a clear pattern of high seasonality; considering the last year with complete information, 2016, in February a month will low demand 164,725 international tourist arrived to the island compared with 2,359,277 tourist in July, the month with the maximum number of arrivals (Spanish Statistic Office, INE, 2016).

This paper has analyzed data for 15 different towns of Mallorca, which differ in their level of seasonality. This research has two main objectives, the first one is to analyze if GDP per capita, unemployment or housing prices are correlated with the level of seasonality, the second one is to understand the importance of adequate infrastructures and if the distance to the main entry point of tourists, the airport, is an explanatory variable for GDP per capita differences. The structure of the paper is as follows, section 2 summarizes the literature review, section 3 clarifies the data and methodology used and the final section covers the main results, their discussion, and future lines of research. 


\section{Literature review}

Seasonality is defined as temporary different impact of tourism, measured by number of tourists, expenditure by tourists, traffic or employment, through the year (Butler, 2001). Seasonality is one of the main characteristics of many touristic destinations (Commons and Page, 2001; Cuccia and Rizzo, 2011, Bigovic, 2012). Scholars have studied the effects that seasonality has in the tourism industry including its effects on profitability, the challenge it suppose for hotels managers, the options policy makers have to try to reduce it or its relation with economic growth.

Hospitality industry is characterized by high fixed cost and a lower occupancy rate in the low demand season affects directly the firm's financial performance (Jeffrey and Barden, 2000). In the competitive environment in which hotels develop their activity differentiation and innovation can help to improve financial performance; Orfila-Sintes et al. (2016) found statistical evidence of a higher effort in innovation by hotels opening all the year rather than just on the peak demand season. Seasonality not only affects the firm performance, also affects the quality of life to people living in these areas. Seasonal employment, underemployment and unemployment are labour market characteristics associated to geographic areas with peak and low demand seasons (Jolliffe and Farnsworth, 2003), in this context firms must decide if to embrace seasonality or to challenge it. However, the policy makers' efforts to reduce seasonality show a mix of results (Koening and Bischoff, 2004) with strategies as diversifying the touristic offer to attract potential new customers in the low demand season, implementing events and festival in the period with less tourist flows or identifying new segments markets with more willingness to visit the area out of the peak demand season.

Most scholars agree that seasonality have negative impacts, the low return due to the difficulties of obtaining adequate revenues in the low demand season act as a barrier for attracting new investment (Getz and Nilsson, 2004); in terms of labour market seasonality makes more difficult to retain talented and skilled workers (Chung,2009). According to Balaguer and Cantevella-Jorda (2002) Spanish economic growth has benefited from tourism, however, high seasonality has a negative impact in productivity levels, hence, with a negative impact on GDP per capita in high seasonality tourist destinations (Croes, 2003). 
A topic that scholars in the field of tourism have addressed is tourism in islands (Gayle, 2002; Sheldon, 2005; Scheyvens and Monsen, 2008). The geographical constrains related to be and islands make difficult to rely on a competitive manufacturing sector and as a consequence the size of tourism in terms of GDP is especially significant in some of them. Obviously, not all villages will benefit to the same extent from the economic activity related to tourists' flows, the location of each village would be a fundamental factor in explaining the importance of tourism activity. Nevertheless, what becomes a relevant decision is the transport infrastructure and where to locate it, because adequate infrastructures would be crucial in developing the tourism industry. Modelling demand has shown that appropriate infrastructures is an explanatory variable with a positive correlation with number of tourists (Khadaroo and Seetanah, 2007). In particular, using regional data several authors have found that the stock of public capital affects positively economic growth, with a significant and positive income elasticity to public stock. This research focus not at regional level, it looks at the evidence from villages in Mallorca with an important touristic sector, considering the distance to the airport as a variable that measure the positive effects associated to transport infrastructures.

Considering the previous literature review the hypothesis proposed are:

H1: Seasonality has a negative impact in the level of GDP per capita.

H2: Higher seasonality positively correlates with higher levels of unemployment.

H3: GDP per capita is positively influenced by being near to the Airport.

\section{Data and Methodology}

To test the hypothesis about seasonality and the effects associated with a nearest location to the Airport data from the island of Mallorca has been selected. Mallorca is one of the most important tourist destinations in Spain, attracting every year more than 5 million international tourists. It is an important sun and beach destination, and as a consequence seasonality is a relevant phenomenon. There are many different alternatives to measure seasonality (Karamustafa and Ulama, 2010), in this research we have measured seasonality using the Gini Index, a well-known indicator used mainly in the measure of inequality income or wealth distribution, but that using the adequate transformation can 
be useful in measuring seasonality. According to Lundtorp (2001) the Gini Index can be measured in tourism as proxy for measuring seasonality considering a demand or supply variable that shows a seasonal pattern. In this article we have considered the number of beds available each month at the villages that have been object of analysis. We define xi as the number of beds available in the month $\mathrm{i}$ (with i taking values from 1 to 12 , ordering the 12 months from the one with the lowest supply to the one with the maximum value); yi is defined as the accumulative number of beds from the first month considered to the month i. The formula to figure out the Gini Index is:

$$
G=\frac{2}{12} \sum_{i=1}^{12}\left(x_{i}-y_{i}\right)
$$

This indicator takes values from 0 to 1 . The extreme value of 1 corresponds to a situation in which all available beds in the year are only available one particular month; the value of 0 corresponds to the lowest level of seasonality and it reflects a situation of homogenous distribution of beds available through the year; a higher value of the indicator is a measure of higher seasonality.

The data related to the 14 villages selected, all of them Mallorca municipalities with tourism as an important contributor the economic activity proceed from the Statistical Office of the Balearic Islands (IBESTAT, 2016). The variables considered have been hotels' room available each month (2015), percentage of the employment in the hospitality industry, total population, distance to the beach, distance to the airport, rate of unemployment, Gross Income per capita and number of firms per capita, the values correspond to the last available data, 2016. Table 2 summarizes the values corresponding to each village, being them ordered from the lowest to the highest level of seasonality.

\begin{tabular}{|l|c|c|c|c|c|c|c|}
\hline Village & $\begin{array}{c}\text { Gini Index, } \\
\text { seasonality }\end{array}$ & Population & $\begin{array}{c}\text { Hospitality } \\
\text { workers as a } \\
\text { share of } \\
\text { employment }\end{array}$ & Unemployment & $\begin{array}{c}\text { Gross } \\
\text { Income } \\
\text { per } \\
\text { capita }\end{array}$ & $\begin{array}{c}\text { Distance } \\
\text { to the } \\
\text { beach } \\
\text { (Km) }\end{array}$ & $\begin{array}{c}\text { Distance } \\
\text { to the } \\
\text { airport } \\
\text { (Km) }\end{array}$ \\
\hline Calvià & 0.3933778 & 50,328 & $21,747 \%$ & $14,68 \%$ & $26,530 €$ & 9,2 & 30,7 \\
\hline Sóller & 0.3981364 & 13,684 & $15,066 \%$ & $11,24 \%$ & $24,860 €$ & 0 & 31,9 \\
\hline Pollença & 0.422354 & 16,115 & $15,671 \%$ & $15,48 \%$ & $24,136 €$ & 0 & 60,7 \\
\hline Capdepera & 0.453831 & 11,420 & $22,646 \%$ & $16,79 \%$ & $18,665 €$ & 0 & 73,2 \\
\hline Son Servera & 0.45433 & 11,449 & $25,982 \%$ & $19,26 \%$ & $19,293 €$ & 0 & 64,2 \\
\hline Muro & 0.463523 & 6,723 & $9,087 \%$ & $15,90 \%$ & $20,066 €$ & 0 & 57,1 \\
\hline $\begin{array}{l}\text { Sant Ll. des } \\
\text { Cardassar }\end{array}$ & 0.46852 & 8,146 & $15,476 \%$ & $12,59 \%$ & $19,753 €$ & 0 & 59,3 \\
\hline Manacor & 0.47057 & 40,170 & $7,570 \%$ & $18,59 \%$ & $21,148 €$ & 16,2 & 50,9 \\
\hline
\end{tabular}




\begin{tabular}{|l|c|c|c|c|c|c|c|}
\hline Ses Salines & 0.47315 & 5,018 & $21,989 \%$ & $15,56 \%$ & $22,139 €$ & 0 & 45,7 \\
\hline Santanyí & 0.4911 & 11,316 & $20,199 \%$ & $17,55 \%$ & $21,792 €$ & 0 & 48,6 \\
\hline Andratx & 0.5000 & 11,093 & $20,456 \%$ & $14,75 \%$ & $23,482 €$ & 7,2 & 39,6 \\
\hline Alcúdia & 0.5090 & 19,763 & $26,328 \%$ & $18,26 \%$ & $22,083 €$ & 0 & 59,6 \\
\hline $\begin{array}{l}\text { Santa } \\
\text { Margalida }\end{array}$ & 0.5099 & 11,672 & $19,789 \%$ & $16,04 \%$ & $21,825 €$ & 11,2 & 56,2 \\
\hline Llucmajor & 0.5977 & 34,618 & $13,036 \%$ & $17,59 \%$ & $24,953 €$ & 17,6 & 21,7 \\
\hline
\end{tabular}

Table 2. Seasonality and main economic variables.

The first hypothesis to test is the negative effect that a high seasonality has in terms of income per capita. Applying the Shapiro-Wilk test we accept that both variables follow normal distribution, hence, their correlation is tested using the Pearson correlation coefficient. The correlation coefficient is negative, -0.085 but is not statistically significant, and hence, the first hypothesis is not accepted.

The second hypothesis tests the existence of a relation between seasonality and higher levels of unemployment. The Pearson correlation is 0.461 , but again not significant. Villages with a level of seasonality below 0.45 show an average rate of unemployment of $15.49 \%$ whereas the villages with seasonality above 0.50 have an average rate of unemployment of $17.30 \%$. Table 3 summarizes these values. These values suggest that working with a higher sample of villages and considering more sun and beach destination would be worthy in terms of concluding the existence of a relation between unemployment and seasonality.

\begin{tabular}{|l|c|}
\hline \multicolumn{1}{|c|}{ Level of seasonality } & Average rate of unemployment \\
\hline Below 0.45 & $15.49 \%$ \\
\hline Between 0.45 and 0.50 & $15.82 \%$ \\
\hline Above 0.5 & $17.30 \%$ \\
\hline
\end{tabular}

Table 3. Seasonality and level of unemployment.

Public capital stock, infrastructures, and in tourism transport infrastructures are a key element in economic development, the fourth hypothesis test the existence of positive relation between distance to the airport and GDP per capita. The Pearson correlation is 0.826 with a p-value 0.000 , hence, this relation is accepted at $1 \%$ significance level. In fact, testing the regression model:

$$
\text { Gross Income per capita } \text { I }_{i}=\beta_{o+} \beta_{1} \text { Distance to the airport }{ }_{i}+\varepsilon_{i}
$$

Table 4 shows the results. 


\begin{tabular}{|l|c|c|}
\hline \multicolumn{1}{|c|}{ Model } & \multicolumn{2}{c|}{ Values } \\
\hline R square & \multicolumn{2}{|c|}{0.682} \\
\hline R square adjusted & 25.786 & 0.656 \\
\hline ANOVA F(1,12) & & 0.000 \\
\hline Constant coefficient (intercept) & $28,856,319$ & $\mathrm{t}=21.178$ \\
& & $\mathrm{p}$-value \\
& & 0.000 \\
\hline Airport distance $(\beta)$ & -133.384 & $\mathrm{t}=-5.087$ \\
& & $\mathrm{p}$-value \\
& & 0.000 \\
\hline
\end{tabular}

Table 4. Regression model analysis.

According to R square and R square adjusted the difference sin Income per Capita can be partially explained by how far is it village from the airport. The $\beta$ value implies that each kilometre far away from the airport reduces the Income per Capita in 133.384€. As a consequence of this fact the decision about how to locate the strategic infrastructures that tourism development needs can have a definitive impact on income distribution and regional inequality.

\section{Results and Discussion}

Scholars have analyzed the impact that seasonality has in firms' performance, human resources management, economic growth or employment. Most of the academic literature agrees that reducing seasonality can have a positive impact and in fact many touristic regions have tried to apply policies to reduce seasonality with mixed results. Many of the empirical studies haven considered regional data, in this context this paper has analyzed municipalities' data, trying to compare if villages in the island of Mallorca with different levels of seasonality show important differences in relevant economic variables.

Unemployment rate correlates negatively $(-0.826)$ with seasonality, however the result is not statistically significant; future research considering a biggest sample of municipalities data would be useful in understanding how seasonality impacts on the labour market. The correlation found between GDP per capita and seasonality was weaker and not significant, perhaps a possible explanation is that employment in the hospitality industry is lower as a percentage of total employment; villages with more seasonality has to develop 
alternative economic activities with higher productivity that compensates the negative effect caused by seasonality; this would be an interesting line of future research.

To analyze how important is the location of the airport in an island that depends to a great extent on tourism a regression considering GDP per capita as a variable depending on the distance to the airport has been used. The results are significant and interesting. Each kilometre of distance to the airport reduces GDP per capita in $133.384 €$; distance to the airport matters, and the model has certain capacity to explore differences in GDP per capita, R square adjusted being 0.656 . This an interesting result not only for scholars, also form policy makers that must consider how the location of the transport infrastructures can affect GDP per capita at municipalities level and have important consequences on terms of inequality. Future research that widens this analysis to other touristic islands would be extremely useful in a better understanding of the relations between public capital stock and economic growth in touristic islands. 


\section{REFERENCES}

Baum, T., \& Hagen, L. (1999). Responses to seasonality: the experiences of peripheral destinations. The International Journal of Tourism Research, 1(5), 299.

Balaguer, J., \& Cantavella-Jorda, M. (2002). Tourism as a long-run economic growth factor: the Spanish case. Applied economics, 34(7), 877-884.

Balearic Islands Statistical Office (IBESCAT). Retrieved from http://www.ibestat.caib.es (Last accessed 20 January 2017).

Bigović, M. (2012). The strength and dynamics of the seasonal concentration in Montenegrin tourism. Institute for Tourism, Zagreb, 16(3).

Cantos, P., Gumbau-Albert, M., \& Maudos, J. (2005). Transport infrastructures, spillover effects and regional growth: evidence of the Spanish case. Transport reviews, 25(1), 2550 .

Butler, R. W. (2001). Seasonality in tourism: Issues and implications. Seasonality in tourism, 5-21.

Capo, J., Font, A. R., \& Nadal, J. R. (2007). Dutch disease in tourism economies: Evidence from the Balearics and the Canary Islands. Journal of sustainable Tourism, 15(6), 615-627.

Commons, J., \& Page, S. (2001). Managing seasonality in peripheral tourism regions: the case of Northland, New Zealand. Seasonality in tourism, 172.

Connell, J., Page, S. J., \& Meyer, D. (2015). Visitor attractions and events: Responding to seasonality. Tourism Management, 46, 283-298.

Croes, R. R. (2003). Growth, development and tourism in a small economy: evidence from Aruba. International Journal of Tourism Research, 5(5), 315-330.

Cuccia, T., \& Rizzo, I. (2011). Tourism seasonality in cultural destinations: Empirical evidence from Sicily. Tourism Management, 32(3), 589-595.

Chung, J. Y. (2009). Seasonality in tourism: A review. E-Review of Tourism Research (eRTR), 7(5), 82-96.

Donatos, G., \& Zairis, P. (1991). Seasonality of foreign tourism in the Greek island of Crete. Annals of Tourism Research, 18(3), 515-519.

Dritsakis, N. (2004). Tourism as a long-run economic growth factor: an empirical investigation for Greece using causality analysis. Tourism Economics, 10(3), 305-316.

Gayle, D. J. (2002). Island tourism and sustainable development: Caribbean, Pacific, and Mediterranean experiences. Greenwood Publishing Group. 
Getz, D., \& Nilsson, P. A. (2004). Responses of family businesses to extreme seasonality in demand: the case of Bornholm, Denmark. Tourism Management, 25(1), 17-30.

Hazari, B. R., \& Sgro, P. M. (2004). Tourism and growth in a dynamic model of trade. In Tourism, Trade and National Welfare (pp. 185-195). Emerald Group Publishing Limited.

Karamustafa, K., \& Ulama, S. (2010). Measuring the seasonality in tourism with the comparison of different methods. EuroMed Journal of Business, 5(2), 191-214.

Khadaroo, J., \& Seetanah, B. (2007). Transport infrastructure and tourism development. Annals of Tourism Research, 34(4), 1021-1032.

Koenig, N., \& Bischoff, E. E. (2004). Seasonality research: the state of the art. European Business Management School.

Jeffrey, D., \& Barden, R. R. (2000). An analysis of daily occupancy performance: a basis for effective hotel marketing?. International Journal of Contemporary Hospitality Management, 12(3), 179-189.

Jolliffe, L., \& Farnsworth, R. (2003). Seasonality in tourism employment: human resource challenges. International Journal of Contemporary Hospitality Management, 15(6), 312-316.

Lundtorp, S. (2001). Measuring tourism seasonality. Seasonality in tourism, 23-50.

Nowak, J. J., \& Sahli, M. (2007). Coastal tourism and'Dutch disease'in a small island economy. Tourism Economics, 13(1), 49-65

Orfila-Sintes, F., Crespí-Cladera, R., \& Martínez-Ros, E. (2005). Innovation activity in the hotel industry: Evidence from Balearic Islands. Tourism Management, 26(6), 851865.

Scheyvens, R., \& Momsen, J. H. (2008). Tourism and poverty reduction: issues for small island states. Tourism Geographies, 10(1), 22-41.

Spanish Statistical Office (INE). Retrieved from http://www.ine.es (last accessed February 2017).

Sheldon, P. J. (2005). The challenges to sustainability in island tourism. Occasional Paper, 1.

Travel and Tourism: Economic impact 2017 (2016). World Travel and Tourism Council. Retrieved from http://www.wttc.org 


\title{
EAMR
}

\section{EUROPEAN ACCOUNTING AND MANAGEMENT REVIEW}

\section{Turnaround Types, Stages, Strategies, and Tactics: Putting Things in Order}

\author{
Sharon Gotteiner \\ Universitat Internacional de Catalunya \\ Marta Mas-Machuca \\ Universitat Internacional de Catalunya \\ Frederic Marimon \\ Universitat Internacional de Catalunya
}

Received December 3, 2018; accepted March 5, 2019.

\begin{abstract}
The turnaround research is still challenged by the inconsistent terminology, hierarchy, and classification of turnaround activities. This study aims to correct such inconsistencies and proposes a synthesized, coherent hierarchy of classifications, namely turnaround stages, strategies, and tactics. Turnaround tactics that are rarely covered by academic studies get indexed and linked to turnaround strategies and stages, while at the same time correcting inconsistencies within the predominant literature. The structure proposed herein can support empirical research of a higher resolution that will go down to specific turnaround tactics and contingencies, as well as support actual decision-making processes faced by executives in challenging business situations.
\end{abstract}

\section{KEYWORDS}




\section{Introduction}

Corporate turnaround research has developed dramatically over the past three decades, as it now offers a wide variety of practices for coping with organizational decline, the classification of such practices, observations regarding the sequence of implementation for such practices, along with case studies to support these observations. However, corporate turnaround research is still empirically and theoretically fragmented, inconsistent, lacking cumulative theory building (Trahms, Ndofor, \& Sirmon, 2013), and under-specified in terms of methodologies and techniques (Safrudin, Rosemann, Recker, \& Genrich, 2014). This situation may still be the result of inconsistent terminology and the inconsistent application of commonly used terms (Pearce \& Robbins, 1993).

Inconsistent terminology and under-specified methodologies lead to confusion and challenge theory building and empirical research. On a basic level, the literature reflects a two-level hierarchy of turnaround activities: activity categories representing "what changes need to be accomplished", and specific activities representing "how to accomplish" such changes (Bibeault, 1999; Hoffman, 1989). The higher-level group is called by various terms, such as "strategies" (Schoenberg, Collier, \& Bowman, 2013), "key set of activities" (Hoffman, 1989), "key ingredients" (Slatter \& Lovett, 1999), and "sets of moves" or "gestalts" (Hambrick \& Schecter, 1983). The lower hierarchy of more specific activities is also referred to by various terms, such as "tactics" (Bibeault, 1999), "isolated moves" (Hambrick \& Schecter, 1983), just "activities" (Robbins \& Pearce, 1992), and even "strategies" (Slatter \& Lovett, 1999). Such confusion leads to a dashed border between the two levels. Thus, both "what changes should be accomplished" -such as cost reduction, divestment, asset reduction, and product-market refocusing - and "how to accomplish" such changes - such as outsourcing, quality improvements, and improved control systems-end up sharing the title: "Turnaround Strategies" (Slatter \& Lovett, 1999). The following is the classification of specific activities like headcount cuts, product elimination, or acquisition as "strategies" (Bibeault, 1999), rather than tactics. When such inconsistency and confusion turn dominant, terminology becomes substance: the distinction between "what changes should be accomplished" and "how to accomplish" such changes is of central importance in developing a hypothesis and selecting analytic data techniques (Hambrick \& Schecter, 1983). The need for consistency in terminology must be addressed to enhance the validity and reproducibility of future studies (Pearce \& 
Robbins, 1993). When these two hierarchies are consolidated, the identification of empirical findings specifically relating to either strategies or tactics becomes difficult.

Drilling down to the "How to accomplish" level, namely "tactics", lists of such tactics are difficult to find in academic studies. For some reason, few academic studies go down to this level of resolution. When they do, some misclassifications are noticeable. For example, tactics such as the reduction of inventories or accounts receivables were often classified under the "cost-efficiencies" or "cost-cutting" strategies, thus suggesting that the reduction of those could lead to immediate profit improvement (Hambrick \& Schecter, 1983; Schoenberg et al., 2013). But inventory and accounts receivable are short-term assets rather than expenses. The liquidation of these assets does not directly affect a firm's income statement. While such tactics deserve a strategy of their own, call it "workingcapital improvement", such a strategy has not been distinguished. Instead, a "consolidated" strategy was created and studied, named "Asset/Cost Surgery" (Hambrick $\&$ Schecter, 1983). When these two are not kept separate, it may become more difficult to reach significant empirical results, or to identify related contingencies. Similarly, very different types of assets were listed under "Asset Retrenchment”. Both short- and longterm assets were included, namely cash and its equivalents, accounts receivable, inventory, plants and equipment (Hambrick \& Schecter, 1983; Robbins \& Pearce, 1992), and subsidiaries/divisions (Sudarsanam \& Lai, 2001). But the reduction of short- and long-term assets serve very different objectives: the reduction of short-term assets aims at generating immediate cash in order to avoid bankruptcy, while the reduction of longterm assets, such as underperforming subsidiaries, would also serve the objective of improving profitability (Bibeault, 1999; Slatter, Lovett, \& Barlow, 2006). As such, while the reduction of short-term assets would typically be applied at the emergency stage of a turnaround, the reduction of long-term assets would be applied at both the emergency and stabilization stages of a turnaround. These are material differences in terms of the turnaround-based change process. Mixing these two types of assets may challenge the ability of identifying empirical differences relating to the timing and sequence of reducing each type, for example. Therefore, mixing these two types of assets under the same category challenges both theory building, and empirical research.

Inconsistencies are also evident within the "what to accomplish" level, namely "strategies". Many studies provided valuable sets of such strategies over the years, but 
the differences between such sets should be reconciled. For example, some turnaround strategies were widely distinguished, namely cost reduction, asset reduction, and strategic focus (Hoffman, 1989; Robbins \& Pearce, 1992; Schoenberg et al., 2013). But other turnaround strategies were neither consistently mentioned nor consistently disputed, namely operational revenue-generation (Bibeault, 1999), culture change (Hoffman, 1989; Schoenberg et al., 2013), increases in strategic position (Hofer, 1980), and stakeholder management (Trahms et al., 2013). In other cases, alleged strategies like acquisitions, the development of new-products, increased penetration into current markets, and penetration into new markets (Hoffman, 1989; Robbins \& Pearce, 1992) were consolidated into a single "building for the future" strategy by others (Schoenberg et al., 2013). If the earlier set of activities actually refers to turnaround tactics rather than strategies, then including them in future research in the wrong hierarchical level may challenge the identification of valuable empirical findings. Similarly, the "management change" strategy (Hoffman, 1989; Schoenberg et al., 2013) was identified elsewhere, not as a strategy, but rather as one of the stages of the turnaround process (Bibeault, 1999). Any study of turnaround stages and strategies, using the wrong classification or hierarchy, would be challenged to contribute valid empirical findings.

Finally, while studies across the board divide the turnaround process into several stages, little consistency is found over the identity of such stages. One common denominator includes the five stages identified by Bibeault (1999): the management change stage, the evaluation stage, the emergency stage, the stabilization stage, and the return-to-normalgrowth stage. From this point on, the decline stage is added before these five (William B. Fredenberger, Lipp, \& Watson, 1997). Alternatively, the emergency and stabilization stages are consolidated into the single retrenchment stage (Pearce \& Robbins, 1993; Robbins \& Pearce, 1992). Such lack of consistency will challenge any research using a set of turnaround stages that is different from the set of stages used by other studies is relies on.

The purpose of this road-show of inconsistencies and confusions surrounding the building blocks of turnaround research is this: to pinpoint and demonstrate the need for putting it all in order and reaching a coherent system of turnaround activities. It has already been indicated that definitional problems and inconsistencies in the field of turnaround research have slowed down empirical progress (Pearce \& Robbins, 1993). If such a 
coherent system of turnaround activities is reached, it will serve as a solid foundation for the next evolutionary stages of turnaround research. Specifically, that will support empirical research of higher resolution, that goes down to specific turnaround tactics and contingencies, as such capable of supporting executives with specific, practical advice.

This study is delivering just that: a reconciled, encapsulated synthesis of the common denominator of the structure and hierarchy of turnaround activities, namely turnaround types, stages, strategies, and tactics. Such a system is served while elaborating on these elements and the common turnaround activities they include.

\section{Turnaround Types}

Turnarounds are widely and consistently classified as either "operational" or "strategic" (Arogyaswamy, Barker, \& Yasai-Ardekani, 1995; Filatotchev \& Toms, 2006; Robbins \& Pearce, 1992; Trahms et al., 2013):

- Operational turnarounds mainly include cost retrenchments and asset retrenchments, whether short-term or long-term. They are triggered by internal factors, such as poor management, inefficient cost structure, non-optimal debt structure, over expansion, or poor control environment, and they aim at fixing the same.

- Strategic turnarounds center on off-loading businesses and increasing market position in the businesses a firm has chosen to retain. They are often triggered by external factors, such as industry, social, macro-economic, or technological factors, and aim at either achieving a better competitive position in the same business or to enter a new business altogether. Such turnaround efforts typically include the investment in, and execution of, strategic repositioning steps, such as acquisitions, new products, new markets, and increased market penetration.

In practice, however, the distinction between strategic and operational turnarounds becomes blurred and not very useful when deciding on the type of turnaround to be selected for a particular situation, therefore, it is not always used (Hambrick \& Schecter, 1983; Hofer, 1980). It could be valuable if future studies examined the usability of this 
distinction between operational and strategic turnarounds by using empirical research over the past three decades. If such distinction is not empirically valuable, it is better to be eliminated rather than to stay and complicate the already-complicated hierarchical structure of turnaround types, stages, strategies, and tactics. If the elimination of unnecessary layers makes organizations more productive (Hitt, Keats, Harback, \& Nixon, 1994; Slatter \& Lovett, 1999; Sutton, 2002; Whitney, 1987), it may do just as well for the turnaround research.

\section{Turnaround Stages}

The predominant literature describes five main stages of a turnaround process: 1) the management-change stage; 2) the evaluation stage; 3) the emergency stage; 4) the stabilization stage, and 5) the return-to-growth stage. The first two stages are turnaroundfacilitating ones. The other three relate to the actual execution of the turnaround strategies and tactics. A company can be involved in strategies and tactics that apply to more than one stage at a time or only some of them, as per the circumstances and the turnaround manager's judgment (Bibeault, 1999).

\subsection{The Management Change Stage}

Stakeholders expect leaders to take charge of their firms and will hold top managers responsible for the firm's performance (Hugh M., 1986; Meindl, Ehrlich, \& Dukerich, 1985). Therefore, replacing the top management team (TMT) is a common practice during a turnaround and is frequently undertaken early in the turnaround process (Grinyer, Mayes, \& McKiernan, 1990; Schoenberg et al., 2013). There are several reasons for such replacements: the current management holds a set of strong, unsuitable business beliefs that led to their blindness, inaction, and failure, and must be unlearned(Arogyaswamy et al., 1995; Daily \& Dalton, 1995; Gopinath, 1991; Nystrom \&Starbuck, 1984; Schuler \& Jackson, 1987); the failure stigmatizes the TMT and leads to them losing credibility and support by either important external stakeholders or firm employees, as such decreasing the TMT's access to vital resources (Arogyaswamy et al., 1995; Hugh M., 1986); TMT changes are also a necessary part of the shock therapy, and change of culture, that troubled companies require (Hartnell, Kinicki, Lambert, Fugate, \& Corner, 2016); a new CEO, 
particularly an outsider, may bring new, more accurate insights, prevent cognitive inertia, and may have little personal commitment to past firm policies and strategies (Arogyaswamy et al., 1995; Barker III, Patterson Jr, \& Mueller, 2001; Castrogiovanni, Baliga, \& Kidwell, 1992); TMT changes eliminate resistance to the change to be led by the new CEO(Slatter et al., 2006); and the replacement itself sends the message of the firm being serious about recovery, symbolizes the decadence of incompetent management, and encourages staff and stakeholders to provide the resources and time required for recovery (Boyne \& Meier, 2009).

However, while some researchers observed this stage to be vital for a successful turnaround (Arogyaswamy et al., 1995; Hofer, 1980), others have observed that a successful turnaround can also be achieved without making such management changes (Clapham, Schwenk, \& Caldwell, 2005; Schreuder, Van Cayseele, Jaspers, \& De Graaff, 1991). Specific contingencies proposed for this stage are when the TMT has demonstrated a track record of the successful implementation of the firm's strategy beforehand (Barker III et al., 2001), or when the decline is attributed to external, uncontrollable causes, such as cyclical recession or industry-wide decline (Barker III \& Duhime, 1997; Hugh M., 1986; O’Kane \& Cunningham, 2012).

\subsection{The Evaluation Stage}

Some key questions should be answered to support the selection of a turnaround plan, which will best suit the firm's situation (Arogyaswamy et al., 1995; William B. Fredenberger et al., 1997; Hugh M., 1986; Robbins \& Pearce, 1992). Examples are (Midanek, 2008; Pretorius, 2008):

- How much time do we have to turn around before we become insolvent?

- What customer needs do we fill?

- Is there a place in the market for our offering at an adequate profitability?

- Where is the problem truly coming from? Which problems should be tackled first?

- $\quad$ Are the firm's stakeholders (shareholders, lenders, management, employees, key suppliers) ready to fund and support a turnaround? 


\subsection{The Emergency Stage}

Cash is the lifeblood of any business, and a negative cash flow must be treated the way a bleeding person is treated. Stopping such a bleed is the main objective of the emergency stage turnaround, while focusing on "quick-wins" in order to stabilize finances in the short term until more complex strategies can be devised. This stage ends as soon as a firm no longer suffers the effects of a negative cash flow (Bibeault, 1999).

\subsection{The Stabilization Stage}

The objective of the stabilization stage is to improve profits. The typical activities it includes are: divesting from underperforming lines of business, operational improvement, low-risk diversification and withdrawing from unprofitable segments, territories, and products. Efforts are made to run existing operations better and to build a sound platform for medium-term growth, while still protecting and purifying the company's profitable core business (Bibeault, 1999).

\subsection{The Return-to-Growth Stage}

The objective of the return-to-growth stage is to achieve growth and the typical activities it includes are: acquisition, new products, new markets, and increasing market penetration. Again, revenue becomes a corporate priority, this time without sacrificing margins (Bibeault, 1999).

\section{Turnaround Strategies and Tactics}

The literature reflects a two-level hierarchy of turnaround activities: strategies and tactics. Turnaround strategies refer to the key set of activities employed to halt decline and stimulate the upturn cycle, representing "what needs to be accomplished". Turnaround tactics refer to isolated, focused activities, specifying "how to accomplish" such turnaround strategies (Hoffman, 1989). Each turnaround strategy can be assigned to one 
or more turnaround stages, as presented in Table 1, and each turnaround tactic can be categorized under one of the turnaround strategies, as presented in Table 2. A review of the support for such a structure and classification will follow.

\begin{tabular}{|l|c|c|c|c|c|}
\hline Turnaround strategy & $\begin{array}{c}\text { Management } \\
\text { change * }\end{array}$ & Evaluation * & Emergency & Stabilization & $\begin{array}{c}\text { Return to } \\
\text { growth }\end{array}$ \\
\hline Financial restructuring & - & - & + & - & - \\
\hline Asset reduction & - & - & + & - & - \\
\hline $\begin{array}{l}\text { Working capital } \\
\text { Improvements }\end{array}$ & - & - & + & $+/-* *$ & - \\
\hline Cost reduction & - & - & + & + & - \\
\hline Revenue generation & - & - & + & + & - \\
\hline Strategic focus & - & - & - & + & - \\
\hline $\begin{array}{l}\text { Critical process- } \\
\text { Improvements }\end{array}$ & - & - & - & + & - \\
\hline Culture change & - & - & - & + & - \\
\hline Growth strategies & - & - & - & - & + \\
\hline
\end{tabular}

* These stages facilitate a turnaround and precede turnaround strategies.

**Selective liquidity improvements only.

Table 1. Turnaround Strategies by Turnaround Stages.

\begin{tabular}{|c|c|}
\hline Turnaround Strategy & Turnaround Tactic \\
\hline \multirow{3}{*}{ Financial restructuring } & Restructuring loans \\
\hline & Reducing dividends \\
\hline & Issuing or repurchasing shares \\
\hline \multirow{2}{*}{ Asset reduction } & Selling unprofitable subsidiaries \\
\hline & Selling unproductive plant and equipment \\
\hline \multirow{6}{*}{$\begin{array}{l}\text { Working-capital } \\
\text { Improvements }\end{array}$} & Managing short-term cash \\
\hline & Freezing selected payments \\
\hline & Selling fixed assets which can be leased \\
\hline & Negotiating extended payment terms with creditors \\
\hline & Reducing investments in inventory \\
\hline & Accelerating billing and collection processes \\
\hline \multirow{9}{*}{ Cost-reduction } & Downsizing excessive workforce \\
\hline & Cutting non-urgent capital expenditures \\
\hline & Cutting non-urgent current expenditures \\
\hline & Negotiating prices with must-continue suppliers \\
\hline & Cutting salaries and benefits, adding performance-based bonuses \\
\hline & Outsourcing processes; converting fixed costs into variable ones \\
\hline & Improving cost-controls \\
\hline & Promoting cost-reduction awareness, involvement, and innovation \\
\hline & Eliminating non-profitable products within viable product lines \\
\hline
\end{tabular}




\begin{tabular}{|c|c|}
\hline Turnaround Strategy & Turnaround Tactic \\
\hline & Redesigning products and manufacturability \\
\hline Revenue generation & Changing prices, focus on cash-generating and profitable products \\
\hline Strategic focus & Shrinking back to the most profitable businesses and segments \\
\hline \multirow{3}{*}{$\begin{array}{l}\text { Critical process } \\
\text { improvements }\end{array}$} & Improving marketing and sales processes \\
\hline & Improving operational processes \\
\hline & Improving key support processes \\
\hline \multirow{4}{*}{ Culture change } & Destroying adverse behaviors \\
\hline & Clarifying the organizational structure, roles, and responsibilities \\
\hline & Implementing Performance Management \\
\hline & Developing innovation \\
\hline \multirow{4}{*}{ Growth strategies } & Developing new product-market positions \\
\hline & Adding or developing new distribution channels \\
\hline & Expanding through acquisitions \\
\hline & Extending joint-ventures, strategic alliances, and partnerships \\
\hline
\end{tabular}

Table 2. Turnaround Tactics by Turnaround Strategies.

\subsection{Financial Restructuring}

A distressed firm that needs to avoid default must restructure the terms of its debt contracts as an alternative for filing for bankruptcy (Gilson, John, \& Lang, 1990). Some researchers consider this emergency-stage strategy to be a precondition for recovering from a cash situation and stabilizing a firm (Filatotchev \& Toms, 2006), although there is no consensus as to its effectiveness (Schoenberg et al., 2013; Sudarsanam \& Lai, 2001).

Restructuring loans: This tactic relates to transactions in which an existing debt is replaced by a new contract, with one or more of the following characteristics: (1) interest or principal reduced, (2) maturity extended, (3) debt-equity swap, and (4) partial debt forgiveness (haircut) (W. B. Fredenberger \& Bonnici, 1994).

Reducing dividends: Distressed firms were widely found to either omit or reduce dividends, while preferring reduction over omission (DeAngelo \& DeAngelo, 1990; Sudarsanam \& Lai, 2001).

Issuing or repurchasing shares: Equity-based tactics include share issues that are pushed by creditors concerned with the security of their lending (Sudarsanam \& Lai, 2001) and 
share repurchasing at a low rate, presumably due to financial distress (John, Lang, \& Netter, 1992).

\subsection{Asset Reduction}

If decline is severe and the risks are high and imminent, a firm should sell its leastproductive operations and assets in order to stop cash-bleed and generate more cash (Filatotchev \&Toms, 2006; W. B. Fredenberger \& Bonnici, 1994; Pearce \& Robbins, 2008, 1993; Robbins \& Pearce, 1992). Tactics under this strategy refer to two different types of assets:

Selling unprofitable subsidiaries: Such subsidiaries should be sold off or milked by raising prices (Roman, 2010; Sudarsanam \& Lai, 2001).

Selling unproductive plant and equipment: Fixed assets that may be good candidates for liquidation or mortgages can be found in the firm's books, especially deeply depreciated ones, if the company has been existed for many years (Hambrick \& Schecter, 1983; Robbins \& Pearce, 1992).

\subsection{Working Capital Improvements}

Working capital refers to a firm's net and current assets. Mathematically, it is calculated by subtracting the firm's current liabilities (e.g. accounts payable, short-term loans) from its current assets (e.g. cash, deposits, accounts receivable, and inventory) (Singhania, Sharma, \& Yagnesh Rohit, 2014). It provides opportunities to relieve some of the cash pressure, make later fundraising from external sources easier, and free cash for investment opportunities (Slatter et al., 2006; Teng, 2010). Typical working-capital related tactics include the following:

Managing short-term cash: Although such a tactic seems to facilitate cash generation, rather than actually generating cash, just introducing a short-term cash-management process by itself can usually improve cash flow (Slatter \& Lovett, 1999; Whitney, 1987). 
Freezing selected payments: Extreme cash situations may require an automatic freeze on all accounts payable and purchase orders that are not required for the firm's survival, until the cash position gets analyzed and clarified and until the business plan is developed(Bibeault, 1999; Slatter et al., 2006).

Selling fixed assets that can be leased: Some capital investments can be replaced with leasing contracts. Such a tactic can be applied to both current investments and future transactions (Bibeault, 1999; Whitney, 1987).

Negotiating extended payment-terms with creditors. Extending creditors' payment terms is another tactic which was found effective in facilitating a turnaround (Filatotchev \& Toms, 2006; Hambrick \& Schecter, 1983; Schoenberg et al., 2013). This tactic is applied aggressively in the emergency stage, and selectively in the stabilization stage (Bibeault, 1999).

Reducing investments in inventory: Reducing inventory is another tactic which was found effective in facilitating a turnaround (Filatotchev \& Toms, 2006; Hambrick \& Schecter, 1983; Schoenberg et al., 2013). A side benefit of this tactic is the realization of savings on storage and carrying costs (Teng, 2010). As such, this tactic is applicable in the emergency and stabilization stages (Bibeault, 1999).

Accelerating billing and collection processes: A reduction in receivables is another tactic that was found to be effective in facilitating a turnaround (Filatotchev \& Toms, 2006; Hambrick \& Schecter, 1983; Schoenberg et al., 2013). This tactic is applied in the emergency and stabilization stages (Bibeault, 1999).

\subsection{Cost Reduction}

Cost reduction refers to "belt-tightening" cutbacks in operating costs for the purpose of quickly increasing profit (reducing loss) or improving cash-flow (Finkin, 1985; Grinyer et al., 1990; O’Neill, 1986; Schoenberg et al., 2013; Sudarsanam \& Lai, 2001). It is applied in both the emergency and stabilization stages of a turnaround, although the focal point is different; cost reduction in the emergency stage centers on decreasing or 
eliminating expenditures that have no measurable payout. During the stabilization stage, cost reductions are refined, modestly upgraded, and focused on specific products and accounts (Bibeault, 1999). Tactics under this strategy are detailed herein.

Downsizing excessive workforce: Downsizing workforce includes the dismissal of an unproductive workforce and/or the avoidance of new hiring (Finkin, 1985; Hitt et al., 1994; Kanter, 2003; Lymbersky, 2014; Pearce \& Robbins, 2008; Perry, 1986).

Cutting non-urgent capital expenditures: This tactic includes the avoidance or reduction of investments and non-current expenditures such as IT systems, office decoration or furniture, and replacement of company cars (Bibeault, 1999).

Cutting non-urgent current expenditures: Expenses that are not required for maintaining smooth operations should be eliminated or reduced, while considering the potential impact of each type of cut (Finkin, 1985; Lymbersky, 2014; Schoenberg et al., 2013).

Negotiating prices with imperative suppliers: This tactic calls for negotiating prices and trading terms with suppliers who are critical for maintaining smooth and compliant operations (Finkin, 1985).

Cutting basic salaries and benefits, adding performance-based bonuses: The primary purpose of this tactic is to get employees to row in the same direction, as required for the company. The secondary purpose is to cut employee benefits (Finkin, 1985; Grinyer et al., 1990; Perry, 1986; Scherrer, 1988; Schoenberg et al., 2013).

Outsourcing processes and converting fixed costs into variable ones: Outsourcing either core or support processes allows for the development of a more efficient, demandresponsive cost structure. It also allows a firm to leverage the specialist capabilities of vendors, standardize processes, focus scarce internal resources on its core business, and avoid non-core distractions (Finkin, 1985; McIvor, 2013).

Improving cost controls: The improvement of cost controls relates to changes in approval requirements for certain types of costs or costs exceeding a certain amount (Grinyer et al., 1990; Hugh M., 1986; Schoenberg et al., 2013). 
Promoting cost-reduction awareness, involvement, and innovation: Internalization of turnaround goals can be achieved by applying two kinds of activities that reflect the impact of new era leadership: symbolic executive actions expressing the need of “tightening the belt" (Armeneikis et al., 1995; Arogyaswamy et al., 1995; O’Reilly, 1989), and the nomination of staff-populated committees, with the mission of reducing costs and increasing productivity (Finkin, 1985).

Eliminate specific, non-profitable products within viable product lines: Most turnaround firms suffer from product proliferation within the product-market segment in which the company competes (Schreuder et al., 1991). Such product proliferation is addressed in the Stabilization stage by eliminating individual, low-margin products within sustainable product lines or by raising their prices and watching how the market reacts (Finkin, 1985).

Redesigning products and manufacturability: Many firms have greatly improved their competitive position by improving the design of their products for cheaper manufacturing and delivery. That includes a higher degree of automation, light assembly, changes in materials and product characteristics, and in the number of component parts (Zimmerman, 1991).

\subsection{Operational Revenue-Generation}

An operational revenue generation strategy refers to attempts to stimulate revenue from existing lines of products through combinations of price changes, discounts, increased marketing expenditures, increased selling efforts, and extended operational hours (Hambrick \& Schecter, 1983; Hofer, 1980; Slatter \& Lovett, 1999; Sutton, 2002). This strategy is used in the emergency and stabilization stages with different focal points:

- $\quad$ Emergency stage - Efforts are aimed at generating cash by either reducing prices (Hofer, 1980) or by increasing prices if products are price insensitive (Bibeault, 1999; Sutton, 2002). 
- Stabilization stage - Efforts are aimed at pushing profitability towards its breakeven point, specifically if the firm has low direct-labor expenses or low fixed costs, which do not leave much room for cost reduction(Hofer, 1980; Sutton, 2002).

\subsection{Strategic Focus}

Focus on the firm's core activities was consistently found to be an effective turnaround strategy so long as the sources of decline are external (Boyne \& Meier, 2009; Pearce \& Robbins, 2008; Schoenberg et al., 2013). Focusing entails determining the markets, segments, niches, products, and customers that have the potential of generating the greatest profits and shrinking back activities towards these areas (Arogyaswamy et al., 1995; Kow, 2004; Schoenberg et al., 2013; Sudarsanam \& Lai, 2001). The divestment of non-profitable, core lines of business frees up scarce marketing and operational and financial resources for reinvestment in the profitable core (Porter, 1988; Stopford \& Baden-Fuller, 1990; Sudarsanam \& Lai, 2001).

\subsection{Critical Process Improvements}

Many performance-improvement methods arose over the years. Examples are the Total Quality Management (TQM), Kaizen, 5S, Lean, Theory of Constraints (TOC), SixSigma, and many more, but many of these methods did not give clear decision support as to which performance areas needed improvement. Also, they offered little support for measurement, did not show an overall improved performance due to ineffective measurements (Grünberg, 2004; Robson, 2004), nor did they indicate alignment with competitive priorities (Carpinetti \& Martins, 2001). Accordingly, success rates while applying such methods were found to be low (Smith, 2002). As far as turnarounds are concerned, operational recovery is about "doing things better" (in contrast to Strategic recovery that calls for "doing better things"). Three main tactics are called for across the board, these are: improving marketing and sales processes, improving operational processes, and improving key support processes. Each type of process may be improved 
from cost, quality, and time perspectives, as well as customer orientation (Kow, 2004; Roman, 2010).

\subsection{Culture Change}

Organizational culture is not always a positive force (O'Reilly, 1989). It is often addressed during turnarounds (Armenakis \& Fredenberger, 1995; Armeneikis et al., 1995; Schoenberg et al., 2013), and has been found to be effective in supporting recovery from poor performance (Muczyk \& Reimann, 1989). Four key culture-related tactics regarding a firm's performance are described as follows:

Destroying adverse behaviors: As decline evolves, adverse behaviors secretly create a culture that makes a bad situation worse (Kanter, 2003). That includes lack of a sense of urgency (Lorange\& Nelson, 1987), organizational "walls", and more (Lorange \& Nelson, 1987). In order to survive, distressed organizations are required for methodological destruction and forgetfulness of old, low-value knowledge, which could be harmful to the sustainable, transformational change (Kow, 2004; Nystrom \& Starbuck, 1984).

Clarifying the organizational structure, roles, and responsibilities: Extraordinary growth and financial success can lead to organizational over-complexity, uncoordinated business units, duplicated efforts and investments, emerging coordination teams and vice presidencies, a massive increase in organizational hierarchy, and a decrease in managerial responsibility. As hierarchical orientation develops, various groups of staff (legal, finance, public affairs) increase their influence to the point where the operating groups lose their client status (Lorange \& Nelson, 1987). Such complicacy is often found at distressed companies and should be simplified and clarified (Slatter et al., 2006).

Implementing performance management: Managers and employees of turnaround companies often do not associate their own goals with the goals of the business in which they work, and they are not held accountable for results. Making them accountable for meeting budgets, targets, and deadlines is the first step in building a results-oriented culture (Bibeault, 1999; Slatter et al., 2006). Practically, the elements supporting such an organizational change were encapsulated in the OPTIMAL MBO formula, where 
OPTIMAL stands for the key ingredients of such implementation, namely: (O) Objectives, Outside-in, (P) Profitability-related goals, (T) Target Setting, (I) Incentives and Influence, (M) Measurement, (A) Agreement, Accountability, Appraisal, Appreciation, and (L) Leadership Support (Gotteiner, 2016).

Developing innovation: Innovation relates to the process of introducing new ways of doing things and implementing them (Kow, 2004; Stopford \& Baden-Fuller, 1990). Developing innovation is an organizational change requiring explicit managerial encouragement and recognition (Lorange \& Nelson, 1987).

\subsection{Growth Strategies}

Growth strategies are implemented when the immediate crisis has passed and the financial position has stabilized (Robbins \& Pearce, 1992), i.e. at the return-to-growth stage. It includes an entrepreneurially driven reconfiguration of assets to support the strong-core growth strategy that the firm has developed, such as broadening a product line or entering new geographies (Pearce \& Robbins, 1993; Schoenberg et al., 2013; Sudarsanam \& Lai, 2001). Such a growth strategy requires more time and cash than is available at the emergency or stabilization stages, therefore should be avoided as long as cash is short (Hofer, 1980; Slatter \& Lovett, 1999). The following tactics are widely described under these strategies:

Developing new product-market positions: Adding products (after eliminating others) was found to be a successful turnaround strategy(Schreuder et al., 1991). This tactic includes the development of new products, new customer segments, or new combinations of products and customer segments (Hugh M., 1986; Pearce \& Robbins, 1993; Sudarsanam \& Lai, 2001).

Adding or developing new distribution channels: Changes in distribution channels were found to be a significant differentiator between successful and unsuccessful turnaround firms (Schreuder et al., 1991). 
Expanding through acquisitions: It may be beneficial for a stabilized firm to acquire another firm that could complement its operations, improve its competitive advantage, reduce its competitive disadvantage, provide access to new distribution channels or new technologies, help take advantage of the economy of scale by combining operations, or improve its debt capacity (Hugh M., 1986; Slatter \& Lovett, 1999).

Extending joint-ventures, strategic alliances, and innovation partnerships: This tactic includes notable collaborative-growth strategies, including joint ventures, strategic alliances (joint projects, licensing), and innovation partnerships (Pearce \& Robbins, 2008).

\section{Limitations and Directions for Future Studies}

Much of the advice from the turnaround literature has tended to be generic with an implicit assumption that the strategies put forward would be effective for all firms, regardless of their particular context or circumstances (Schoenberg et al., 2013). It may possibly only be the focus of academic research, aiming at generalizing case-based insights. Such a focus on generic activities may be required in order to cope with a common concern about case studies - that they provide little basis for scientific generalization (Yin, 2009). This study continues that tendency for generalization by analyzing the predominant literature and identifying its common denominator in terms of turnaround stages, strategies, and tactics. Such a generalization was required in this study in order to achieve the objective of clarifying the hierarchy of turnaround activities reflected by that predominant literature and prevent the future use of inconsistent terminology and research design. But once such a consistent structure and terminology is reached, future research may be able to identify additional, effective turnaround strategies on top of the ones already identified as effective. Such a possibility exists where past empirical studies relied on previous studies that did not share consistent terminology and classifications. As such, this study calls for the continued search of effective turnaround strategies on top of the ones described in this study, while focusing on the strategies found to be ineffective in the past. 
Once a clear and consistent structure and hierarchy of turnaround stages, strategies, and tactics is reached, extensive research of a higher resolution, namely at the tactical level, can be supported. Most of the turnaround studies over the years analyzed turnaround stages and strategies, without getting down to the more practical level of turnaround tactics. Such a practical level was mostly offered by practitioners' manuscripts. Possible inconsistent hierarchy and terminology challenged the research of such higher-resolution level: Reaching solid findings, based on prior studies that use inconsistent terminology and hierarchies of activities, is a challenge. But once a consistent structure, hierarchy, and terminology is used, future studies may be able to produce valuable findings at the tactical level. Specifically, it could be valuable to identify which turnaround tactics are more common or more effective than others - just as Schoenberg, Collier, and Bowman (2013) did at the strategic level. As such, this research calls for extensive higher-resolution research, namely at the tactical level of the turnaround process.

Finally, this paper does not cover the sequence or timing of execution of the various strategies and tactics described or any contingencies. As far as turnaround strategies are concerned, timing, sequence, and contingencies are widely covered by the predominant literature. But coverage of the same at the tactical level has not yet been reached. After offering a consistent structure and classification of turnaround strategies and tactics, this study calls for exploring the same at the tactical level. Specifically, it calls for identifying effective sequences, timing, and contingencies for various turnaround tactics, given the specific turnaround strategy being pursued. For example, companies pursuing a costreduction strategy can be studied in terms of the sequence of tactics being used: are tactics that do not involve layoffs being exhausted before implementing the tactic of reducing excessive workforce? Under which contingencies do they, or don't? Similarly, companies pursuing growth strategies can be studied for their prioritization of related tactics: under which conditions would the acquisition of other businesses take place before implementing organic tactics, such as expanding distribution channels or developing new products? A better understanding of sequences, timing, and contingencies at the tactical level may generate valuable observations, required at the practical level, that are currently yet to be explored. 


\section{Limitations and Directions for Future Studies}

The predominant turnaround literature has tended to be elusive in terms of terminology, hierarchy, and classification of turnaround activities. That insufficiency was indicated by several researchers in this field over the years, and it challenged the progress of both theory-building and empirical research. In addition, the specific tactics that are being applied during turnarounds have not been widely studied. This paper aims at putting the terminology, hierarchy, and classification of turnaround activities in order, while at the same time synthesizing and indexing such activities for the sake of supporting enhanced research of corporate turnaround. It starts by selecting a set of basic terminology to distinguish types of activities from isolated activities, namely turnaround strategies and tactics. Simplification of the overall structure was proposed by eliminating the layer of turnaround type, whether strategic or operational, for questioned practical value. The layers of turnaround stages, strategies, and tactics were described in detail, while linking strategies to stages, classifying tactics into strategies, and correcting or reconciling inconsistencies within the predominant literature. Proposed takeaways from this study are as follows:

- A complete turnaround process includes five stages: management change, evaluation, emergency, stabilization, and return to growth. The first two stages are process-facilitating ones, and the other three cover the actual execution of the turnaround process.

- While progressing along the turnaround process and stages, nine generic strategies make up the common denominator of predominant literature: financial restructuring, asset reduction, working-capital improvements, cost-reduction, revenue generation, strategic focus, critical process improvements, culture change, and growth strategies.

- Each turnaround strategy calls for a set of turnaround tactics, which were systematically described.

While corporate turnaround research seems to be in need of more consistency, the synthesized structure presented above may reduce the levels of inconsistencies and confusion surrounding the building blocks of turnaround research. As such this structure may serve as a solid foundation for empirical research and for theories to build on. In 
addition, most academic papers did not research the higher-resolution level of turnaround tactics. Therefore, the map of turnaround tactics provided in this study, as well as its linkage with turnaround strategies and stages, can provide new opportunities for turnaround research, which would be closer to the decision-making process faced by corporate executives upon challenging business situations. 


\section{REFERENCES}

Armenakis, A. A., \& Fredenberger, W. B. (1995). Process strategies for turnaround change agents: Crisis and non-crisis situations. Strategic Change, 4(1), 19-31.

Armeneikis, A., Fredenberger, W., Cherones, L., Feild, H., Giles, W., \& Holley, W. (1995). Symbolic Actions Used By Business Turnaround Change Agents. Academy of Management Best Papers Proceedings. https://doi.org/10.5465/AMBPP.1995.17536499

Arogyaswamy, K., Barker, V. L., \& Yasai-Ardekani, M. (1995). Firm Turnarounds: an Integrative Two-Stage Model. Journal of Management Studies. https://doi.org/10.1111/j.1467-6486.1995.tb00786.x

Barker III, V. L., \& Duhime, I. M. (1997). STRATEGIC CHANGE IN THE TURNAROUND PROCESS: THEORY AND EMPIRICAL EVIDENCE. Strategic Management Journal. https://doi.org/10.1002/(SICI)1097-0266(199701)18:1<13::AIDSMJ843>3.3.CO;2-O

Barker III, V. L., Patterson Jr, P. W., \& Mueller, G. C. (2001). Organizational Causes and Strategic Consequences of the Extent of Top Management Team Replacement During Turnaround Attempts. Journal of Management Studies. https://doi.org/10.1111/14676486.00235

Bibeault, D. B. (1999). Corporate turnaround: how managers turn losers into winners! Washington, DC: Beard Books.

Boyne, G. A., \& Meier, K. J. (2009). Environmental change, human resources and organizational turnaround. Journal of Management Studies. https://doi.org/10.1111/j.1467-6486.2008.00813.x

Carpinetti, L. C. R., \& Martins, R. A. (2001). Continuous improvement strategies and production competitive criteria: Some findings in Brazilian industries. Total Quality Management. https://doi.org/10.1080/09544120120034438

Castrogiovanni, G. J., Baliga, B. R., \& Kidwell, R. E. (1992). Curing sick businesses: Changing CEOs in turnaround efforts. Academy of Management Executive. https://doi.org/10.5465/AME.1992.4274176

Clapham, S. E., Schwenk, C. R., \& Caldwell, C. (2005). CEO perceptions and corporate turnaround. Journal of Change Management. https://doi.org/10.1080/14697010500359276

Daily, C. M., \& Dalton, D. R. (1995). CEO and director turnover in failing firms: An illusion of change? Strategic Management Journal. https://doi.org/10.1002/smj.4250160505

DeAngelo, H., \& DeAngelo, L. (1990). Dividend Policy and Financial Distress: An Empirical Investigation of Troubled NYSE Firms. The Journal of Finance. https://doi.org/10.1111/j.1540-6261.1990.tb03721.x 
Filatotchev, I., \& Toms, S. (2006). Corporate governance and financial constraints on strategic turnarounds. Journal of Management Studies. https://doi.org/10.1111/j.14676486.2006.00596.x

Finkin, E. F. (1985). Company Turnaround. Journal of Business Strategy. https://doi.org/10.1108/eb039082

Fredenberger, W. B., \& Bonnici, J. (1994). Turnaround phases: Extending the life cycle theory. American Business Review, 12(1), 59.

Fredenberger, W. B., Lipp, A., \& Watson, H. J. (1997). Information requirements of turnaround managers at the beginning of engagements. Journal of Management Information Systems. https://doi.org/10.1080/07421222.1997.11518147

Gilson, S. C., John, K., \& Lang, L. H. P. (1990). Troubled debt restructurings. An empirical study of private reorganization of firms in default. Journal of Financial Economics. https://doi.org/10.1016/0304-405X(90)90059-9

Gopinath, C. (1991). Turnaround: Recognizing decline and initiating intervention. Long Range Planning. https://doi.org/10.1016/0024-6301(91)90048-S

Gotteiner, S. (2016). The OPTIMAL MBO: A Model for Effective Management-byObjectives Implementation. European Accounting and Management Review, 2, 42-56.

Grinyer, P. H., Mayes, D., \& McKiernan, P. (1990). The sharpbenders: Achieving a sustained improvement in performance. Long Range Planning. https://doi.org/10.1016/0024-6301(90)90013-T

Grünberg, T. (2004). Performance improvement: Towards a method for finding and prioritising potential performance improvement areas in manufacturing operations. International Journal of Productivity and Performance Management. https://doi.org/10.1108/17410400410509969

Hambrick, D. C., \& Schecter, S. M. (1983). Turnaround Strategies for Mature IndustrialProduct Business Units. Academy of Management Journal. https://doi.org/10.2307/255972

Hartnell, C. A., Kinicki, A. J., Lambert, L. S., Fugate, M., \& Corner, P. D. (2016). Do similarities or differences between CEO leadership and organizational culture have a more positive effect on firm performance? A test of competing predictions. Journal of Applied Psychology. https://doi.org/10.1037/ap10000083

Hitt, M. A., Keats, B. W., Harback, H. F., \& Nixon, R. D. (1994). Rightsizing: Building and maintaining strategic leadership and long-term competitiveness. Organizational Dynamics. https://doi.org/10.1016/0090-2616(94)90066-3

Hofer, C. W. (1980). Turnaround strategies. Journal of Business Strategy. https://doi.org/10.1108/eb038886 
Hoffman, R. C. (1989). Strategies for corporate turnarounds: what do we know about them? Journal of General Management, 14(3), 46-66.

Hugh M., O. (1986). Turnaround and recovery: What strategy do you need? Long Range Planning.

John, K., Lang, L. H. P., \& Netter, J. (1992). The Voluntary Restructuring of Large Firms In Response to Performance Decline. The Journal of Finance. https://doi.org/10.1111/j.1540-6261.1992.tb03999.x

Kanter, R. M. (2003). Leadership and the Psychology of Turnarounds. Harvard Business Review.

Kow, G. (2004). Turning around business performance: Part II. Journal of Change Management. https://doi.org/10.1080/1469701042000259640

Lorange, P., \& Nelson, R. T. (1987). How to Recognize and Avoid Organizational Decline. Sloan Management Review.

Lymbersky, C. (2014). International Turnaround Management Standard. Hamburg: Turnaround Management Society.

McIvor, R. (2013). Employing business improvement techniques to improve performance and reduce risk in services outsourcing. The Institute of Chartered Accountants of Scotland (ICAS).

Meindl, J. R., Ehrlich, S. B., \& Dukerich, J. M. (1985). The Romance of Leadership James R . Meindl. Administrative Science Quarterly. https://doi.org/10.2307/2392813

Midanek, D. H. (2008). Cultivating Companies: Growing Value Using Turnaround Management Techniques. The Journl of Private Equity. https://doi.org/Article

Muczyk, J. P., \& Reimann, B. C. (1989). MBO as a Complement to Effective Leadership. The Academy of Management Executive (1987). https://doi.org/10.5465/AME.1989.4274763

Nystrom, P. C., \& Starbuck, W. H. (1984). To avoid organizational crises, unlearn. Organizational Dynamics. https://doi.org/10.1016/0090-2616(84)90011-1

O'Kane, C., \& Cunningham, J. (2012). Leadership Changes and Approaches During Company Turnaround. International Studies of Management and Organization. https://doi.org/10.2753/IMO0020-8825420403

O'Neill, H. M. (1986). AN ANALYSIS OF THE TURNAROUND STRATEGY IN COMMERCIAL BANKING. Journal of Management Studies. https://doi.org/10.1111/j.1467-6486.1986.tb00418.x

O'Reilly, C. (1989). Corporations, Culture, and Commitment: Motivation and Social Control in Organizations. California Management Review. https://doi.org/10.2307/41166580 
Pearce, J. A., \& Robbins, D. K. (2008). Strategic transformation as the essential last step in the process of business turnaround. Business Horizons. https://doi.org/10.1016/j.bushor.2007.11.003

Pearce, J. A., \& Robbins, K. (1993). Toward Improved Theory and Research on Business Turnaround. Journal of Management. https://doi.org/10.1177/014920639301900306

Perry, L. T. (1986). Least-cost alternatives to layoffs in declining industries. Organizational Dynamics. https://doi.org/10.1016/0090-2616(86)90043-4

Porter, M. E. (1988). From competitive advantage to corporate strategy. McKinsey Quarterly. https://doi.org/Article

Pretorius, M. (2008). When Porter's generic strategies are not enough: Complementary strategies for turnaround situations. Journal of Business Strategy. https://doi.org/10.1108/02756660810917200

Robbins, D. K., \& Pearce, J. A. (1992). Turnaround: Retrenchment and recovery. Strategic Management Journal. https://doi.org/10.1002/smj.4250130404

Robson, I. (2004). From process measurement to performance improvement. Business Process Management Journal. https://doi.org/10.1108/14637150410559199

Roman, I. (2010). Turnaround strategies for customer centric operations: Turn by turn directions on the path to recovery. Toronto, Canada: Italics Publishing Inc.

Safrudin, N., Rosemann, M., Recker, J. C., \& Genrich, M. (2014). A typology of business transformations. The $360^{\circ}$ Business Transformation Journal.

Scherrer, P. S. (1988). From Warning To Crisis A Turnaround Primer. Management Review.

Schoenberg, R., Collier, N., \& Bowman, C. (2013). Strategies for business turnaround and recovery: A review and synthesis. European Business Review. https://doi.org/10.1108/09555341311314799

Schreuder, H., Van Cayseele, P., Jaspers, P., \& De Graaff, B. (1991). Successful bearfighting strategies. Strategic Management Journal. https://doi.org/10.1002/smj.4250120705

Schuler, R. S., \& Jackson, S. E. (1987). Linking Competitive Strategies with Human Resource Management Practices. Academy of Management Executive. https://doi.org/10.5465/AME.1987.4275740

Singhania, M., Sharma, N., \& Yagnesh Rohit, J. (2014). Working capital management and profitability: evidence from Indian manufacturing companies. DECISION. https://doi.org/10.1007/s40622-014-0043-3 
Slatter, S., \& Lovett, D. (1999). Corporate turnaround: Managing companies in distress. London: Penguin Books.

Slatter, S., Lovett, D., \& Barlow, L. (2006). Leading Corporate Turnaround: How Leaders Fix Troubled Companies. Jossey-Bass.

Smith, M. E. (2002). Success Rates for Different Types of Organizational Change. International Society for Performance Improvement. https://doi.org/10.1002/pfi.4140410107

Stopford, J. M., \& Baden-Fuller, C. (1990). Corporate Rejuvenation. Journal of Management Studies. https://doi.org/10.1111/j.1467-6486.1990.tb00254.x

Sudarsanam, S., \& Lai, J. (2001). Corporate Financial Distress and Turnaround Strategies: An Empirical Analysis. British Journal of Management. https://doi.org/10.1111/1467-8551.00193

Sutton, G. (2002). The six month fix: Adventures in rescuing failing companies. John Wiley \& Sons, Inc.

Teng, M. (2010). Corporate Turnaround: Nursing a sick company back to health. Singapore: Mentor Media Printing Pte Ltd.

Trahms, C. A., Ndofor, H. A., \& Sirmon, D. G. (2013). Organizational Decline and Turnaround: A Review and Agenda for Future Research. Journal of Management. https://doi.org/10.1177/0149206312471390

Whitney, J. O. (1987). Turnaround Management Every Day. Harvard Business Review. https://doi.org/Article

Yin, R. (2009). Case Study Research Design and Methods Fourth Edition. Applied Social Research Methods Seiries. https://doi.org/10.1097/FCH.0b013e31822dda9e

Zimmerman, F. M. (1991). The Turnaround Experience: Real World Lessons in Revitalizing Corporations. New York, NY: McGraw-Hill. 


\title{
EAMR
}

\section{EUROPEAN ACCOUNTING AND MANAGEMENT REVIEW}

\section{A Simplified Balanced 'Balanced Scorecard'}

\author{
Ivan Malbasic \\ University of Zagreb \\ Frederic Marimon \\ Universitat Internacional de Catalunya
}

Received December 12, 2018; accepted January 11, 2019.

\begin{abstract}
This paper proposes a performance measurement system (PMS) based on the Balanced Scorecard (BSC) that requires only 25 common key performance indictors (KPIs), which are characterized by their easiness to collect, in turn making the PMS an affordable instrument for all types of organizations, regardless of their resource availability. This is particularly relevant for SMEs.

A sample of 813 surveys collected from managers in the Republic of Croatia is analyzed through structural equation modeling. The proposed simplified BSC shows good psychometric features, and the relationships found among the four classical perspectives are consistent with the literature, which provides homological validity for the model.

This paper also proves that the equilibrium among the four perspectives has a significant impact on three perspectives, vouching for the importance of this balance among perspectives. It further shows the extent to which strategy influences the four perspectives.

The proposed simplified BSC may interest both academics and practitioners as it does not require any special knowledge or additional resources to be implemented and monitored while also highlighting (i) the importance of strategy in the design of the model (ii) and the importance of balance among perspectives.
\end{abstract}

\section{KEYWORDS}

Balanced scorecard, performance measurement system, small and medium-sized enterprises, key performance indicators. 


\section{Introduction}

Kaplan and Norton (1996) introduced the Balanced Scorecard (BSC) at the end of the 20th century as an instrument to measure an organization's performance and, at the same time, as a way to deploy its strategy. Since then, many organizations have applied and used it (Hoque 2014). The success of this particular performance measurement system (PMS) has been extensively analyzed. Different organizations have different motives for using it (e.g., Rodrigues Quesado et al. (2017) adapts it to non-profit organizations). Lueg and Carvalho e Silva (2013) analyzes how BSC has been modified to match different industries and organizational levels. Consequently, each organization 'customizes' the model to pursue its particular aims. Some organizations use mainly financial indicators and only a few non-financial indicators, whereas others use indicators from the four key business perspectives - financial, customers, internal business processes, and learning and growth. PMSs have evolved from having a purely financial perspective to having a more strategic outlook (Hurtado González et al. 2012).

Kaplan and Norton (1996) claim that all business perspectives are useful and necessary to measure organizational performance and assess its evolution over time. This approach also enables the introduction of innovations that guarantee overall improvement and provides material for effective benchmarking. It requires each organization to collect its own key performance indicators (KPIs) depending on available resources, sectors of activity and other relevant factors (Kasurinen 2002). Small and medium enterprises (SME) in particular devote few resources to designing a PMS and collecting information to feed the system.

To provide a consistent and effective PMS for SMEs, this paper proposes a system based on the BSC that requires few KPIs to minimize implementation and monitoring costs. Hence, these KPIs are easy to collect and monitor while remaining universal, thus enabling benchmarking among these organizations. Kaplan and Norton (1996) state, furthermore, that the four aforementioned perspectives are required and that a harmonic balance among them through time helps an organization to excel. These considerations introduce two new central issues as follows: (i) to what extent does strategy definition affect the four original perspectives and (ii) to what extent does the degree of balance 
among the four perspectives of a BSC impact these perspectives as well as strategy deployment?

The purpose of this paper is thus twofold. The first is to propose a simple and universal PMS based on BSC that takes into account all four perspectives and that can be used by any SME. Because this instrument is based on BSC, the second objective of this paper has three components as follows: (i) verifying whether the perspectives of the proposed PMS affect one another as expected and providing evidence for its homological validity, (ii) analyzing the impact of strategy on the four perspectives and (iii) analyzing to what extent the degree of balance among perspectives impacts these four perspectives and strategy deployment.

Thus, fresh view on the causal-effect between perspectives will be provided, and the original contribution is the analysis the impact of both (i) strategy and (ii) balance among perspectives on the four BSC perspectives. On the other hand, all this new approach is useful for SME, which due to different motivations prefer using a simple and reduced BSC, composed for few KPIs that can be collected easily.

The rest of the paper is structured as follows. A literature review is provided in section two along with justification of the hypotheses. In the third section, we provide an extended explanation of the balanced BSC proposed. Section four describes the methodology and results. Finally, the fifth section provides the discussion and conclusions, including some study limitations.

\section{Literature review and hypotheses}

\subsection{The Balanced Scorecard}

Kaplan and Norton $(1992,1996)$ developed the most widely used model for measuring organizational effectiveness. Amado et al. (2012) particularly analyze the impact of the BSC use on the organization effectiveness. This model contains not only traditional financial performance measures focused on the past but also indicators that initiate future actions in the organization (Kaplan and Norton 1996; Wade and Recardo 2001; Celma et 
al. 2017), taking into account four business perspectives (Kaplan and Norton 1996; Kumbakara 2008). The relationship among BSC measures is described in Kaplan and Norton (1996), in both text and figures. It assumes a causal relationship between the learning and growth perspective and the financial perspective, mediated by the other two perspectives, customers and internal business practices (Kaplan and Norton 1996, pp. 3, $72,111,113,129,152$ and 160). Some studies analyze the cause-and-effect chain among the perspectives of the BSC empirically. Nørreklit (2000), for instance, examines the extent to which such cause-and-effect relationships exist among the four BSC perspectives, whereas Bryant et al. (2004) use cross-sectional data on seven archival measures of the BSC perspectives. Moreover, analyzing the concept of BSC, Čizmić and Crnkić (2010) show an even stronger connection between key perspectives of the BSC. According to them, the BSC is designed as a series of causal relationships, both within and between perspectives, resulting in achievement of financial objectives.

Based on the causality implicit in the model, three sub-hypotheses are stated (based on Epstein and Manzoni 1997; Martinsons et al. 1999; Mooraj et al. 1999; Atkinson 2006; Carton and Hofer 2006):

H1a: Higher levels of 'learning and growth' perspective are positively related to higher levels of 'internal business processes' perspective.

H1b: Higher levels of 'internal business processes' perspective are positively related to higher levels of 'customers' perspective.

H1c: Higher levels of 'customers' perspective are positively related to higher levels of 'financial' perspective.

The hypothesis underlying these three sub-hypotheses is that the proposed balanced BSC behaves in the same way as the original BSC.

\subsection{The impact of strategy on the four perspectives}

The BSC was initially established to cover four key business perspectives. However, Kaplan and Norton indicated that it is necessary to link BSC measures with company 
strategy, stating that "a successful Balanced Scorecard is one that communicates a strategy through an integrated set of financial and nonfinancial measurements" (1996, p. 147). In considering specific situations for using BSC, such as applications in small enterprises and in the public sector, some authors suggest it is useful to explicitly include indicators of a more general, or strategic, perspective to connect all the other perspectives (Morisawa and Kurosaki 2003; Bryant et al. 2004; Moullin 2004; Atkinson 2006; Huang et al. 2009; Parmenter 2010; Janeš 2014). This strategic perspective could supplement other perspectives, giving the overall PMS a note of company personality.

As one of the purposes of the BSC is to assist with strategy implementation, Kaplan and Norton (1996) argue that its metrics must measure those activities that lead to strategy implementation. Consequently, both Nanni et al. (1992) and Atkinson (2006) state that an integrated PMS has to be aligned with company strategy. Given that a good BSC should be customized based on a company's business strategy, four sub-hypotheses are proposed to test the relationship between strategy implementation and each of the four original BSC perspectives:

H2a: Higher levels of 'strategy implementation' are positively related to higher levels of 'learning and growth' perspective.

H2b: Higher levels of 'strategy implementation' are positively related to higher levels of 'internal business processes’ perspective.

H2c: Higher levels of 'strategy implementation' are positively related to higher levels of 'customers' perspective.

H2d: Higher levels of 'strategy implementation' are positively related to higher levels of 'financial' perspective.

\subsection{Equilibrium among perspectives}

The essence of the BSC concept reflects the balance "between short- and long-term objectives, between financial and nonfinancial measures, between lagging and leading indicators, and between external and internal performance perspectives" (Kaplan and 
Norton 1996, p. viii). To achieve such equilibrium, it is necessary to combine several different indicators into a single framework (Daft 2010, p. 77), and the BSC enables exactly that. The BSC can therefore be viewed as a holistic system that may encompass all (or at least the most important) stakeholders of the company, simultaneously providing strategic reflection and implementation (Mooraj et al. 1999; Ittner et al. 2003; De Geuser et al. 2009; Cheffi et al. 2010).

Considering the importance of aligning different measurements with strategy to ensure a holistic view of the organization, we introduce the concept of Balanced Index for the Balanced Scorecard (BSC BI). Kaplan and Norton (1996, p. 34) report that "the four perspectives of the Balanced Scorecard have been found to be robust across a wide variety of companies and industries". Subsequent papers adapt this framework to various sectors of activity, settings and cultural environments. Nevertheless, the concept of 'balance' embedded in the label of the system has not been analyzed in depth. We suggest revisiting Kaplan and Norton's suggestion that the instrument itself needs to be balanced. The stronger the balance, the higher the scores in each perspective because all perspectives are influencing each other according to the proposed model. Stefanovska and Soklevski (2014, p. 165) go even further, claiming that a BSC "provides equilibrium between multiple perspectives that will enable the organization to develop equally all of its organizational capacities". In the next section we propose a procedure to capture this equilibrium or balance among the four perspectives. Below we propose the following five sub-hypotheses (based on Olsson et al. 2000; Osama 2006; Funck 2007; Stefanovska and Soklevski 2014; Shin et al. 2015):

H3a: Higher levels of 'BSC BI' are positively related to higher levels of 'learning and growth' perspective.

H3b: Higher levels of 'BSC BI' are positively related to higher levels of 'internal business processes' perspective.

H3c: Higher levels of 'BSC BI' are positively related to higher levels of 'customers' perspective.

H3d: Higher levels of 'BSC BI' are positively related to higher levels of 'financial' perspective. 
H3e: Higher levels of 'BSC BI' are positively related to higher levels of 'strategy implementation' perspective.

The main hypothesis underlying these five sub-hypotheses is that the more balanced the $\mathrm{BSC}$, the higher the levels of the four perspectives and strategy implementation.

\subsection{Research model}

The model in Figure 1 summarizes the twelve sub-hypotheses. The solid lines show the three sub-hypotheses testing consistency of the model with the literature (Taticchi et al. 2010; Lueg and Carvalho e Silva 2013; Janeš 2014), whereas the dotted lines correspond to the second and third sets of sub-hypotheses assessing the impact of strategy and the degree of balance of the BSC on the four perspectives. As aforementioned, the first set of hypotheses provides a fresh view on an issue extensively analyzed in the literature and it is represented in solid lines in Figure 1, while the second and third sets of hypotheses are new analysis, and scarcely previous literature exists (mainly for the last set) and are shown in doted lines, meaning that this is an exploratory ground.

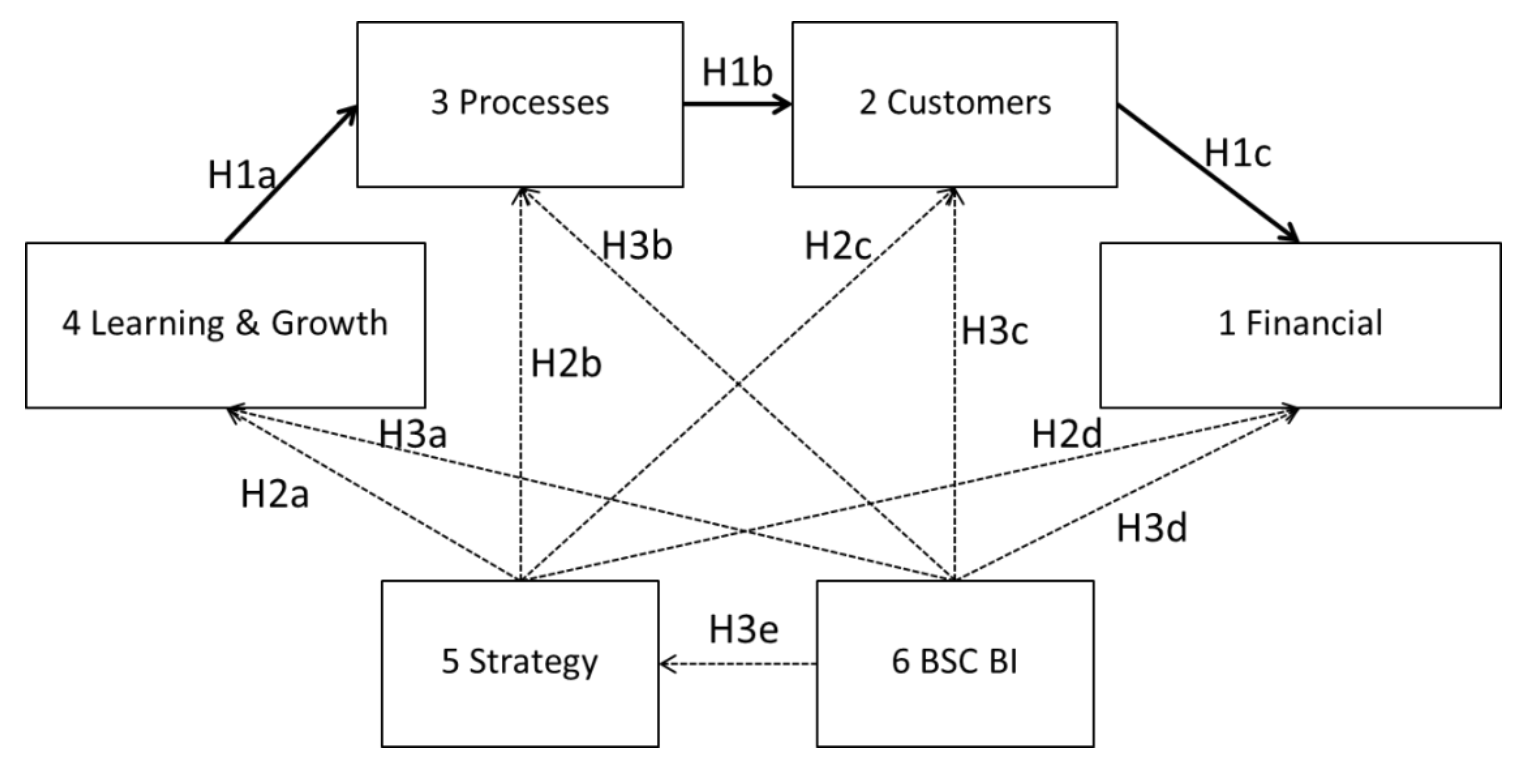

Figure 1. Research model showing the relationship between the BSC and the BI BSC. 


\section{A balanced BSC}

Measuring organizational effectiveness using the $\mathrm{BSC}$ is a comprehensive and universally accepted method. One critical weakness of this method is that it utilizes operational measures that are unique to each organization (Carton and Hofer 2006, p. 42). Therefore, difficulties occur in attempting to measure the effectiveness of different organizations with the same criteria (i.e., indicators). Given that the systematic and precise measurement of organizational effectiveness through a full application of BSC is a complex, lengthy and expensive process, we propose a method for measuring overall organizational effectiveness in a simplified way using 25 of the most common generic indicators of organizational effectiveness. Selecting five KPIs per perspective is not far removed from what Kaplan and Norton (1996) use. Salterio (2012) uses between four and seven measures for each perspective. Based on these defined weighted indicators, a measure of the effectiveness of each organization is calculated as the sum of all indicators.

In the proposed method, we obtain information on organizational effectiveness through different sources, depending on the specific indicator. We collect data on organizational effectiveness through interviews with top management, a purpose-made questionnaire, and an analysis of publicly available financial reports. The assumption is that data collected in this way provide a real and complete picture of organizational effectiveness.

This method relies on the BSC approach (Kaplan and Norton 1996). Based on the analysis of a number of studies proposing common/generic KPIs, performance indicators are selected for each BSC perspective. These indicators are listed below in Table 1, along with references justifying the inclusion of each of the 25 chosen universal KPIs. 
Perspective Generic indicators
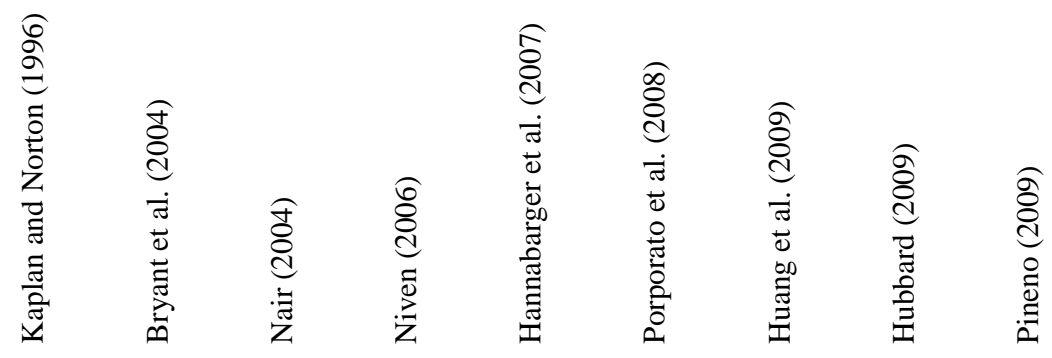

Financial

F1. Income
growth rate

The average

revenue growth

rate on an annual

basis reduced by

the amount of

financial and

extraordinary

income.

\begin{tabular}{lll}
\hline $\begin{array}{l}\text { F2. Net profit } \\
\text { margin }\end{array}$ & $\begin{array}{l}\text { The ratio of } \\
\text { profitability } \\
\text { calculated as net } \\
\text { profit (after tax) } \\
\text { divided by total } \\
\text { revenues. }\end{array}$ & + \\
& $\begin{array}{l}\text { The ratio } \\
\text { between total } \\
\text { revenues and } \\
\text { total expenses, } \\
\text { i.e., between } \\
\text { outcomes and } \\
\text { costs. Business }\end{array}$ & +
\end{tabular}

\begin{tabular}{ll}
\hline F4. Return on & The percentage \\
investment & $\begin{array}{l}\text { of net profit (after } \\
\text { tax) from }\end{array}$
\end{tabular}

investment

undertaken to

achieve this

profit.

F5. Credit rating General term for

the criteria or

benchmarks

determining the

ability of the

borrower to repay

a loan, i.e.,

creditworthiness.

Customers C1. Market share The proportion of

business in a

given market (in

terms of numbers

of customers,

earned money, or

unit volume sold)

that an

organization

captures. 


\begin{tabular}{|c|c|c|c|c|c|c|c|c|c|c|c|}
\hline $\begin{array}{l}\text { C2. Customer } \\
\text { satisfaction }\end{array}$ & $\begin{array}{l}\text { Customer opinion } \\
\text { about the } \\
\text { organization or } \\
\text { its } \\
\text { products/services, } \\
\text { based on a } \\
\text { comparison of } \\
\text { the perceived } \\
\text { features with } \\
\text { their own } \\
\text { expectations. }\end{array}$ & + & + & + & + & + & & & & + & + \\
\hline $\begin{array}{l}\text { C3. Customer } \\
\text { retention }\end{array}$ & $\begin{array}{l}\text { The rate at which } \\
\text { an organization } \\
\text { retains or } \\
\text { maintains } \\
\text { ongoing } \\
\text { relationships with } \\
\text { its customers. }\end{array}$ & + & & + & + & + & & & & + & + \\
\hline $\begin{array}{l}\text { C4. New } \\
\text { customer } \\
\text { acquisition }\end{array}$ & $\begin{array}{l}\text { The rate at which } \\
\text { an organization } \\
\text { attracts or wins } \\
\text { new customers or } \\
\text { business. }\end{array}$ & + & & & + & + & + & & + & & + \\
\hline $\begin{array}{l}\text { C5. Customer } \\
\text { relationship }\end{array}$ & $\begin{array}{l}\text { Planned and } \\
\text { sustained effort } \\
\text { to establish and } \\
\text { maintain good } \\
\text { relations and } \\
\text { mutual } \\
\text { understanding } \\
\text { between an } \\
\text { organization and } \\
\text { its customers. }\end{array}$ & + & & + & + & & & & & & \\
\hline $\begin{array}{l}\text { P1. Quality of } \\
\text { products/services }\end{array}$ & $\begin{array}{l}\text { The ability of a } \\
\text { product or } \\
\text { service to meet or } \\
\text { exceed } \\
\text { customers' } \\
\text { expectations. }\end{array}$ & + & & + & & + & & & & & + \\
\hline $\begin{array}{l}\text { P2. New product } \\
\text { introductions }\end{array}$ & $\begin{array}{l}\text { New product } \\
\text { implies changing } \\
\text { or adding } \\
\text { usefulness and/or } \\
\text { a new way of } \\
\text { using existing } \\
\text { products, as well } \\
\text { as the } \\
\text { introduction of a } \\
\text { completely new } \\
\text { product. }\end{array}$ & + & + & + & & + & & & & + & + \\
\hline $\begin{array}{l}\text { P3. Level of } \\
\text { capacity use }\end{array}$ & $\begin{array}{l}\text { The ratio between } \\
\text { the achieved } \\
\text { output and } \\
\text { working capacity. }\end{array}$ & & & + & & + & & & & & \\
\hline $\begin{array}{l}\text { P4. Work } \\
\text { productivity }\end{array}$ & $\begin{array}{l}\text { The ratio between } \\
\text { the realized } \\
\text { amount (of }\end{array}$ & & & + & + & + & + & + & + & & + \\
\hline
\end{tabular}




\begin{tabular}{|c|c|c|c|c|c|c|c|c|c|c|c|}
\hline & $\begin{array}{l}\text { products) and the } \\
\text { amount of human } \\
\text { labor required to } \\
\text { realize it. }\end{array}$ & & & & & & & & & & \\
\hline $\begin{array}{l}\text { P5. Response } \\
\text { time }\end{array}$ & $\begin{array}{l}\text { The time elapsed } \\
\text { from when the } \\
\text { customer sent a } \\
\text { request (inquiry, } \\
\text { order, complaint, } \\
\text { etc.) until that } \\
\text { request has been } \\
\text { successfully } \\
\text { solved. }\end{array}$ & + & & + & + & + & & & & + & + \\
\hline $\begin{array}{l}\text { L1. Employee } \\
\text { satisfaction }\end{array}$ & $\begin{array}{l}\text { Employee's } \\
\text { attitude toward } \\
\text { work that } \\
\text { significantly } \\
\text { affects work } \\
\text { motivation, and } \\
\text { even the } \\
\text { employee's life as } \\
\text { a whole. }\end{array}$ & + & & + & + & & + & & & + & + \\
\hline $\begin{array}{l}\text { L2. Employee } \\
\text { productivity }\end{array}$ & $\begin{array}{l}\text { Outcome measure } \\
\text { of the aggregate } \\
\text { impact of } \\
\text { enhancing } \\
\text { employee skills } \\
\text { and morale, } \\
\text { fostering } \\
\text { innovation, } \\
\text { improving } \\
\text { internal processes, } \\
\text { and satisfying } \\
\text { customers, } \\
\text { thereby relating } \\
\text { the output } \\
\text { produced by } \\
\text { employees to the } \\
\text { number of } \\
\text { employees used to } \\
\text { produce that } \\
\text { output. }\end{array}$ & + & + & + & + & + & & & & + & \\
\hline $\begin{array}{l}\text { L3. Information } \\
\text { systems } \\
\text { capabilities }\end{array}$ & $\begin{array}{l}\text { Measure that } \\
\text { indicates if an } \\
\text { organization's } \\
\text { information } \\
\text { systems support } \\
\text { key business } \\
\text { processes and } \\
\text { enable collection } \\
\text { and comparison } \\
\text { of relevant } \\
\text { business } \\
\text { information. }\end{array}$ & + & & & & + & & & & & + \\
\hline $\begin{array}{l}\text { L4. Continuous } \\
\text { improvement of } \\
\text { processes }\end{array}$ & $\begin{array}{l}\text { The extent to } \\
\text { which an } \\
\text { organization } \\
\text { continuously }\end{array}$ & + & & + & + & + & + & + & + & + & \\
\hline
\end{tabular}




\begin{tabular}{|c|c|c|}
\hline & $\begin{array}{l}\text { improves its } \\
\text { equipment, } \\
\text { methods, } \\
\text { materials, and } \\
\text { especially its } \\
\text { business } \\
\text { processes. }\end{array}$ & \\
\hline $\begin{array}{l}\text { L5. Education } \\
\text { and training of } \\
\text { employees }\end{array}$ & $\begin{array}{l}\text { The extent to } \\
\text { which an } \\
\text { organization } \\
\text { continuously } \\
\text { improves the } \\
\text { knowledge and } \\
\text { skills of their } \\
\text { employees. }\end{array}$ & + \\
\hline $\begin{array}{l}\text { S1. Precise } \\
\text { business } \\
\text { objectives }\end{array}$ & $\begin{array}{l}\text { The extent to } \\
\text { which business } \\
\text { goals are clearly } \\
\text { and precisely } \\
\text { defined, as well as } \\
\text { aligned across } \\
\text { different levels of } \\
\text { management. }\end{array}$ & \\
\hline $\begin{array}{l}\text { S2. Mission } \\
\text { achievement }\end{array}$ & $\begin{array}{l}\text { The extent to } \\
\text { which an } \\
\text { organization } \\
\text { achieves its } \\
\text { mission (primary } \\
\text { purpose), i.e., has } \\
\text { generated } \\
\text { conditions to } \\
\text { achieve it within } \\
\text { the planned } \\
\text { period. }\end{array}$ & \\
\hline $\begin{array}{l}\text { S3. Business } \\
\text { transparency }\end{array}$ & $\begin{array}{l}\text { The extent to } \\
\text { which insight into } \\
\text { a company's } \\
\text { business } \\
\text { operations is } \\
\text { provided not only } \\
\text { to shareholders } \\
\text { and employees } \\
\text { but also to the } \\
\text { general public. }\end{array}$ & $\begin{array}{l}\text { (Strategic indicators are selected and developed based on Batstone 2003; Moullin 2004; } \\
\text { Nair 2004; Niven 2006; Hannabarger 2007; Hubbard 2009; Thanaraksakul and Phruksaphanrat } \\
\text { 2009; Hill and Jones 2010; Parmenter 2010; David 2011; Hitt et al. 2011; Wheelen and Hunger } \\
\text { 2012, as well as on experiences from contemporary business practice) }\end{array}$ \\
\hline $\begin{array}{l}\text { S4. } \\
\text { Environmental } \\
\text { protection }\end{array}$ & $\begin{array}{l}\text { The extent to } \\
\text { which } \\
\text { environmental } \\
\text { protection is an } \\
\text { indispensable part } \\
\text { of the company's } \\
\text { business policy. }\end{array}$ & \\
\hline $\begin{array}{l}\text { S5. Concern for } \\
\text { the community }\end{array}$ & $\begin{array}{l}\text { The extent to } \\
\text { which an } \\
\text { organization } \\
\text { thinks of itself as } \\
\text { part of a wider } \\
\text { community, }\end{array}$ & \\
\hline
\end{tabular}




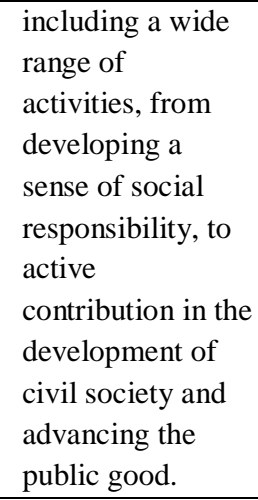

Table 1. Selected generic indicators of organizational effectiveness distributed among the BSC perspectives and key references

A study conducted by Soderberg et al. (2011) shows that the term 'balanced scorecard' is usually interpreted in different ways among managers and other organizational members, thus resulting in inconsistent definition and implementation of the PMS, which often diverges significantly from the construct envisioned by Kaplan and Norton (1996). This is the main reason it makes sense to define a set of generic performance indicators for key business perspectives. Such an approach implies that all five business perspectives (strategic included) are equally important, but within them the importance and significance of individual KPIs can vary from company to company. An analysis of the generic indicators listed in Table 1 highlights some of their common features as follows: widespread across industries and countries, generic, unique, universal, easy to collect (from employee surveys, manager interviews, and available data from open sources), intuitive, and reliable from a psychometric point of view.

Given that we are comparing the effectiveness of organizations that differ based on a number of criteria (e.g., size, core business, etc.), only relative indicators are used to measure effectiveness. Unlike absolute indicators, which represent specific values expressed in the original measurement units (e.g., value of stocks, total revenue, number of complaints, etc.), relative indicators are derived from absolute indicators by calculation.

Organizational effectiveness has already been defined as the degree to which an organization achieves its goals. However because each organization defines its own specific objectives, not all effectiveness indicators are equally important for all organizations. Therefore, after evaluating indicators within a particular BSC perspective, 
these indicators are ranked according to the strength of their influence within that same perspective, separately for each organization. This is done such that each perspective establishes one square matrix containing all effectiveness indicators of the observed perspective in its columns and rows. Cells of this matrix indicate relationships between two different indicators. Table 2 shows a comparison of the selected effectiveness indicators using the financial perspective as an example. This table also shows how to calculate the strength of each indicator as required in Table 3.

\begin{tabular}{lccccc}
\hline Effectiveness indicators & F-1 & F-2 & F-3 & F-4 & F-5 \\
\hline F-1. Income growth rate & - & F-2 & F-1 & F-4 & F-5 \\
F-2. Net profit margin & - & - & F-2 & F-2 & F-2 \\
F-3. Business efficiency & - & - & - & F-4 & F-5 \\
F-4. Return on investment & - & - & - & - & F-4 \\
F-5. Credit rating & - & - & - & - & - \\
\hline Number of cells with the indicator F-i & 1 & 4 & 0 & 3 & 2 \\
\hline Ranking of the indicator F-i & 4 & 1 & 5 & 2 & 3 \\
\hline Strength of indicator F-i & $2 / 15$ & $5 / 15$ & $1 / 15$ & $4 / 15$ & $3 / 15$ \\
\hline
\end{tabular}

Table 2. Example of determining the importance of effectiveness indicators within a particular BSC perspective (the financial perspective)

\begin{tabular}{lccc}
\hline $\begin{array}{c}\text { Indicators of financial } \\
\text { perspective }\end{array}$ & $\begin{array}{c}\text { Indicator } \\
\text { assessment } \\
(1-5)\end{array}$ & $\begin{array}{c}\text { Weight } \\
\text { (strength of) } \\
\text { indicator }\end{array}$ & $\begin{array}{c}\text { Weighted } \\
\text { indicator score }\end{array}$ \\
\hline Income growth rate & 3 & $2 / 15$ & 0.400 \\
Net profit margin & 4 & $5 / 15$ & 0.667 \\
Business efficiency & 2 & $1 / 15$ & 0.333 \\
Return on investment & 5 & $4 / 15$ & 1.067 \\
Credit rating & 2 & $3 / 15$ & 0.400 \\
\hline \multicolumn{4}{r}{} \\
\hline
\end{tabular}

Table 3. Example of determining the weighted score of the financial perspective

The ultimate goal of this method for measuring overall organizational effectiveness is to calculate the Index of organizational effectiveness (IOE), a measure that expresses the effectiveness of a particular organization by taking into consideration indicators of key BSC perspectives. In doing so, these indicators are ranked according to their importance for the particular organization for which the measure is calculated. In other words, once the weighted indicator scores for each of the five perspectives are determined, these scores must be summed, and then divided by the total number of perspectives. The quotient obtained, as shown in the example in Table 4, is the Index of organizational effectiveness of a particular organization. 


\begin{tabular}{lcc}
\hline \multicolumn{1}{c}{ Perspective } & $\begin{array}{c}\text { Total weighted score for the } \\
\text { perspective }\end{array}$ & $\begin{array}{c}\mid \text { (Total weighted score for the } \\
\text { perspective })- \text { IOE) })\end{array}$ \\
\hline Financial & 2.867 & 0.353 \\
Customers & 4.032 & 0.812 \\
Internal business processes & 2.230 & 0.990 \\
Learning and growth & 3.275 & 0.055 \\
Strategic & 3.694 & 0.474 \\
\hline The total sum of all BSC & 16.098 & 2.684 \\
perspectives: & Index of Organizational & BSC Balanced \\
& Effectiveness (IOE): & Index (BCS BI): \\
& 16.098/5 = 3.220 & $2.684 / 5=0.537$ \\
\hline
\end{tabular}

Table 4. Example of how to calculate the Index of organizational effectiveness (IOE) and the Balanced Index for the Balanced Scorecard (BSC BI)

Associated to IOE, Table 4 also calculates the 'Balanced Index' that captures the degree of imbalance among BSC perspectives (BSC BI). The most 'balanced' BSC is that in which the five perspectives are assessed with the same punctuation, which yields a BSC BI of zero.

\section{Methodology and results}

A questionnaire was designed to collect the required information and was completed by 874 respondents from 24 different companies in the Republic of Croatia in 2014. The survey includes companies from 6 different counties, out of 21 counties in Croatia. The number of employees in surveyed companies varies between 216 and 1100, with an average of 513. The companies vary widely by sector-from different types of manufacturing to building and construction, design, consulting and research, insurance, publishing, telecommunications, television programming and broadcasting, warehousing and transportation logistics, wholesale and retail, and wholesale of pharmaceutical goods. After examining all completed questionnaires, a total of 813 valid responses are obtained. The sample shows a gender bias, as 485 respondents are women. Two thirds of respondents are under 44 years old, and more than half have been serving at their company less than ten years. 
The six variables of the model are computed as explained in previous sections. Table 5 shows the descriptive statistics of the variables. The first five variables range from one to five, whereas the last (BSC BI) is calculated as explained in the previous section.

\begin{tabular}{|c|c|c|c|c|c|c|}
\hline & & & & & & \\
\hline & 1 & 2 & 3 & 4 & 5 & 6 \\
\hline 1 Financial & 1.000 & & & & & \\
\hline 2 Customers & 0.467 & 1.000 & & & & \\
\hline 3 Internal business processes & 0.378 & 0.449 & 1.000 & & & \\
\hline 4 Learning and growth & 0.505 & 0.425 & 0.629 & 1.000 & & \\
\hline 5 Strategic & 0.591 & 0.534 & 0.625 & 0.687 & 1.000 & \\
\hline 6 BSC BI & -0.668 & -0.268 & -0.276 & -0.198 & -0.241 & 1.000 \\
\hline Mean & 3.268 & 3.816 & 3.605 & 3.707 & 3.856 & 0.343 \\
\hline Standard deviation & 0.916 & 0.573 & 0.484 & 0.576 & 0.536 & 0.316 \\
\hline
\end{tabular}

Table 5. Statistics of the variables

Path analysis using EQS software is chosen to analyze the regressions implied in the research model. The structural model is estimated by using the maximum likelihood method from the asymptotic variance-covariance matrix.

The fit indices obtained in the measurement model estimation show good general fit. $\chi^{2}$ is 47.42 with 3 degrees of freedom and a p-value of 0.000 . RMSEA is 0.135 , and the comparative fit index (CFI) is 0.979 . All sub-hypotheses are confirmed at a confidence level of $95 \%((*)$ Significant at 5\% level

Table 6), with the exception of $\mathrm{H} 3 \mathrm{a}$, thus providing sufficient evidence to accept the three main hypotheses.

\begin{tabular}{llcc}
\hline Hypothesis & $\begin{array}{c}\text { Path coefficient } \\
\text { (standardized } \\
\text { solution) }\end{array}$ & t-value \\
\hline H1a & Learning and growth $\rightarrow$ Internal business processes & $0.370\left(^{*}\right)$ & 10.252 \\
H1b & Internal business processes $\rightarrow$ Customers & $0.163(*)$ & 3.993 \\
H1c & Customers $\rightarrow$ Financial & $0.106(*)$ & 5.173 \\
H2a & Strategy $\rightarrow$ Learning and growth & $0.679\left(^{*}\right)$ & 28.130 \\
H2b & Strategy $\rightarrow$ Internal business processes & $0.342(*)$ & 8.476 \\
H2c & Strategy $\rightarrow$ Customers & $0.402(*)$ & 10.521 \\
H2d & Strategy $\rightarrow$ Financial & $0.403(*)$ & 17.938
\end{tabular}




$\begin{array}{llcc}\mathrm{H} 3 \mathrm{a} & \mathrm{BSC} \mathrm{BI} \rightarrow \text { Learning and growth } & -0.035 & -1.224 \\ \mathrm{H} 3 \mathrm{~b} & \mathrm{BSC} \mathrm{BI} \rightarrow \text { Internal business processes } & -0.120\left(^{*}\right) & -4.209 \\ \mathrm{H} 3 \mathrm{c} & \mathrm{BSC} \mathrm{BI} \rightarrow \text { Customers } & -0.126\left(^{*}\right) & -3.354 \\ \mathrm{H} 3 \mathrm{~d} & \mathrm{BSC} \mathrm{BI} \rightarrow \text { Financial } & -0.524\left(^{*}\right) & -28.493 \\ \mathrm{H} 3 \mathrm{e} & \mathrm{BSC} \mathrm{BI} \rightarrow \text { Strategy } & -0.241(*) & -7.322\end{array}$

(*) Significant at 5\% level

Table 6. Hypotheses results for the structural model

The three sub-hypotheses $\mathrm{H} 1$ are confirmed, providing evidence that the impact flow among the four perspectives is consistent with the literature, showing homological validity.

The four sub-hypotheses $\mathrm{H} 2$ are also confirmed, suggesting that strategy deployment has a positive impact on each of the perspectives. Note that the higher paths of the model are those that show the impact of the 'strategy' construct on the four perspectives, in accordance with Kaplan and Norton (1996) and Atkinson (2006).

Finally, four out of the five sub-hypotheses H3 are also confirmed, giving support to our last proposition: the more balanced the BSC among the four perspectives, the higher the score organizations obtain in the four perspectives, as well as in the strategy construct. Note the negative sign in these paths because the lower the BSC BI index, the more balanced the scorecard.

\section{Discussion and conclusions}

We have proposed a BSC simple enough to be used by any organization, no matter its size or resources available to monitor it. The results of this study not only confirm assumptions about causal relationships implicit in the BSC model as suggested by previous studies (e.g., Nørreklit 2000; Bryant et al. 2004) but also suggest that even a simplified and balanced BSC behaves in the same way as the original BSC. The balanced BSC proves consistent with previous literature in terms of the relationship among its perspectives, proving its homological internal consistency. Furthermore, this 
measurement system is based in only 25 KPIs that are easily collected because most organizations use them as part of regular management. This also enables benchmarking across organizations, making comparisons feasible and consistent. Moreover, this makes the proposed model particularly interesting for SMEs. Needless to say the managerial implications derived from this simplified BSC for SME. These organizations are neither able to devote resources to define a complex SME nor to monitorize it. The proposed BSC enables not only implementing and monitorizing it, but also the analysis and improving proposals, influencing the entire Plan-Do-Check-Act Deming cycle.

It is also well established that the BSC "provides a framework, a language, to communicate mission and strategy" (Kaplan and Norton 1996, p. 25). However, business practice shows that some key elements of strategy are often not measured in the BSC. Today, organizations must pay attention to environmental protection and concern for the community, as well as business transparency. These are just some examples of KPIs that are not represented in the standard BSC perspectives. In this paper we explain the importance of embedding strategy in BSC design, and hypothesis testing unambiguously indicates that higher levels of 'strategy implementation' are positively related to all four standard BSC perspectives.

Another contribution of this paper, perhaps the most important, is to introduce the measurement of the 'balance' or 'equilibrium' of the four perspectives, through the Balanced Index for the Balanced Scorecard (BSC BI). This study shows that higher levels of BSC BI are positively related to higher levels of almost all key BSC perspectives (except for the learning and growth perspective). These results strongly indicate the need for balancing different business perspectives, which should be evident at all levels of the company from setting goals to balancing organizational values. Our findings are consistent with those of Kaplan and Norton (1996), who claim that "the four perspectives of the BSC have been found to be robust across a wide variety of companies and industries". In addition, the four perspectives should display equivalent scores to show harmonious strategy deployment.

Finally, some limitations of the study should be noted. The first limitation relates to the sample, which was restricted to Croatian companies. Future studies should be conducted with larger samples and should cover a wider geographical area. Moreover, the adequacy 
to different activity sectors could also be addressed in future, and also the fit of the model to different size companies. Another limitation concerns the fact that the BSC is actually a management system for improving organizational performance (Kaplan and Norton 1996, p. ix), whereas in this study, BSC was primarily used as a technique for capturing/measuring the current state of organizational effectiveness. 


\section{REFERENCES}

Amado, C. A., Santos, S. P., \& Marques, P. M. (2012) 'Integrating the Data Envelopment Analysis and the Balanced Scorecard approaches for enhanced performance assessment', Omega, 40(3), 390-403.

Atkinson, H. (2006) 'Strategy Implementation: A Role for the Balanced Scorecard?', Management Decision, 44(10), 1441-1460.

Batstone, D. (2003) Saving the Corporate Soul - \& (Who Knows?) Maybe Your Own: Eight Principles for Creating and Preserving Wealth and Well-Being for You and Your Company Without Selling Out, John Wiley \& Sons: San Francisco, CA.

Bryant, L., Jones, D.A., Widener, S.K. (2004) 'Managing Value Creation within the Firm: An Examination of Multiple Performance Measures', Journal of Management Accounting Research, 16(1), 107-131.

Carton, R.B., Hofer, C.W. (2006) Measuring Organizational Performance: Metrics for Entrepreneurship and Strategic Management Research, Edward Elgar Publishing: Cheltenham.

Celma, D., Buil, M., Patau, J. (2017) 'Management control in startups with high growth success in the Technology sector: The case of Netrivals', European Accounting and Management Review, 3(2), 17-44.

Cheffi, W., Rao, A., Beldi, A. (2010) 'Designing a Performance Measurement System: Accountants and Managers Diverge', Management Accounting Quarterly, 11(3), 8-21.

Čizmić, E., Crnkić, K. (2010) 'Enhancing Organizational Effectiveness and Efficiency through Balanced Scorecard Application', Problems and Perspectives in Management, 8(4), 14-26.

Daft, R.L. (2010) Organization Theory and Design, 10th ed, South-Western Cengage Learning: Mason, $\mathrm{OH}$.

David, F.R. (2011) Strategic Management: Concepts and Cases, 13th ed, Prentice Hall: Upper Saddle River, NJ.

Epstein, M.J., Manzoni, J.-F. (1997) 'The Balanced Scorecard and Tableau de Bord: A Global Perspective on Translating Strategy into Action', Management Accounting, 79(2), $28-36$.

Funck, E. (2007) 'The Balanced Scorecard Equates Interests in Healthcare Organizations', Journal of Accounting \& Organizational Change, 3(2), 88-103.

De Geuser, F., Mooraj, S., Oyon, D. (2009) 'Does the Balanced Scorecard Add Value? Empirical Evidence on its Effect on Performance', European Accounting Review, 18(1), 93-122. 
Hannabarger, C. (2007) Balanced Scorecard Strategy for Dummies, Wiley Publishing: Hoboken, NJ.

Hill, C.W.L., Jones, G.R. (2010) Strategic Management Theory: An Integrated Approach, 9th ed, South-Western/Cengage Learning: Mason, $\mathrm{OH}$.

Hitt, M.A., Ireland, R.D., Hoskisson, R.E. (2011) Strategic Management Concepts: Competitiveness and Globalization, 9 th ed, South-Western Cengage Learning: Australia ; Mason, $\mathrm{OH}$.

Hoque, Z. (2014). '20 years of studies on the balanced scorecard: trends, accomplishments, gaps and opportunities for future research', The British accounting review, 46(1), 33-59.

Huang, H.-C., Chu, W., Lai, M.-C., Lin, L.-H. (2009) 'Strategic Linkage Process and Value-Driven System: A Dynamic Analysis of High-Tech Firms in a NewlyIndustrialized Country', Expert Systems with Applications, 36(2), 3965-3974.

Hubbard, G. (2009) 'Measuring Organizational Performance: Beyond the Triple Bottom Line', Business Strategy and the Environment, 18(3), 177-191.

Hurtado González, J.M., Calderón, M.Á., Galán González, J.L. (2012) 'The Alignment of Managers' Mental Models with the Balanced Scorecard Strategy Map', Total Quality Management \& Business Excellence, 23(5-6), 613-628.

Ittner, C.D., Larcker, D.F., Randall, T. (2003) 'Performance Implications of Strategic Performance Measurement in Financial Services Firms', Accounting, Organizations and Society, 28(7-8), 715-741.

Janeš, A. (2014) 'Empirical Verification of the Balanced Scorecard', Industrial Management \& Data Systems, 114(2), 203-219.

Kaplan, R.S., Norton, D.P. (1992) 'The Balanced Scorecard - Measures That Drive Performance', Harvard Business Review, 70(1), 71-79.

Kaplan, R.S., Norton, D.P. (1996) The Balanced Scorecard: Translating Strategy into Action, Harvard Business School Press: Boston, MA.

Kasurinen, T. (2002) 'Exploring Management Accounting Change: The Case of Balanced Scorecard Implementation', Management Accounting Research, 13(3), 323-343.

Kumbakara, N. (2008) 'Managed IT Services: The Role of IT Standards', Information Management \& Computer Security, 16(4), 336-359.

Lueg, R., Carvalho e Silva, A.L. (2013) 'When One Size does not Fit All: A Literature Review on the Modifications of the Balanced Scorecard', Problems and Perspectives in Management, 11(3), 86-94. 
Martinsons, M., Davison, R., Tse, D. (1999) 'The Balanced Scorecard: A Foundation for the Strategic Management of Information Systems', Decision Support Systems, 25(1), 71-88.

Mooraj, S., Oyon, D., Hostettler, D. (1999) 'The Balanced Scorecard: A Necessary Good or an Unnecessary Evil', European Management Journal, 17(5), 481-491.

Morisawa, T., Kurosaki, H. (2003) 'Using the Balanced Scorecard in Reforming Corporate Management Systems', Nomura Research Institute Papers, (71), 1-15.

Moullin, M. (2004) 'Evaluating a Health Service Taskforce', International Journal of Health Care Quality Assurance, 17(5), 248-257.

Nair, M. (2004) Essentials of Balanced Scorecard, Essentials series, John Wiley \& Sons: Hoboken, NJ.

Nanni, A.J., Dixon, J.R., Vollmann, T.E. (1992) 'Integrated Performance Measurement: Management Accounting to Support the New Manufacturing Realities', Journal of Management Accounting Research, 4, 1-19.

Niven, P.R. (2006) Balanced Scorecard Step-by-Step: Maximizing Performance and Maintaining Results, 2nd ed, John Wiley \& Sons: Hoboken, NJ.

Nørreklit, H. (2000) 'The Balance on the Balanced Scorecard a Critical Analysis of Some of Its Assumptions', Management Accounting Research, 11(1), 65-88.

Olsson, B., Karlsson, M., Sharma, E. (2000) 'Towards a Theory of Implementing the Balance Scorecard: A Study in Association with the Swedish Telecommunication Firm Ericsson', Journal of Human Resource Costing \& Accounting, 5(1), 59-84.

Osama, A. (2006) Multi-Attribute Strategy and Performance Architectures in R\&D: The Case of The Balanced Scorecard, PhD Thesis.

Parmenter, D. (2010) Key Performance Indicators: Developing, Implementing, and Using Winning KPIs, 2nd ed, John Wiley \& Sons: Hoboken, NJ.

Pineno, C.J. (2009) 'Simulation of the Weighting of Balanced Scorecard Metrics Based on the Product Life Cycle', The Coastal Business Journal, 8(1), 85-100.

Porporato, M., Basabe, M., Arellano, J. (2008) 'Commonality and Standardization of Balanced Scorecard's Measures across Perspectivas', Revista del instituto internacional de costos, (2), 113-131.

Rodrigues Quesado, P., Frenandes Branco, J. C., Rodrigues, F. J. (2017) 'Proposal to Implement the Balanced Scorecard in a Non-profit Organization', European Accounting and Management Review, 4(1), 49-74.

Salterio, S. (2012) 'Balancing the Scorecard through Academic Accounting Research: Opportunity Lost?', Journal of Accounting \& Organizational Change, 8(4), 458-474. 
Shin, J., Choi, J., Kim, I. (2015) 'Development of BIM Performance Measurement System for Architectural Design Firms', in Celani, G., Sperling, D.M. and Franco, J.M.S., eds., Computer-Aided Architectural Design Futures. The Next City - New Technologies and the Future of the Built Environment, Springer Berlin Heidelberg: Berlin, Heidelberg, 348-365.

Soderberg, M., Kalagnanam, S., Sheehan, N.T., Vaidyanathan, G. (2011) 'When is a Balanced Scorecard a Balanced Scorecard?', International Journal of Productivity and Performance Management, 60(7), 688-708.

Stefanovska, L., Soklevski, T. (2014) 'Benefits of Using Balanced Scorecard in Strategic and Operational Planning', Universal Journal of Management, 2(4), 165-171.

Taticchi, P., Tonelli, F., Cagnazzo, L. (2010) 'Performance Measurement and Management: A Literature Review and a Research Agenda', Measuring Business Excellence, 14(1), 4-18.

Thanaraksakul, W., Phruksaphanrat, B. (2009) 'Supplier Evaluation Framework Based on Balanced Scorecard with Integrated Corporate Social Responsibility Perspective', in Proceedings of the International MultiConference of Engineers and Computer Scientists (Vol II), Presented at the IMECS 2009, Hong Kong.

Wade, D., Recardo, R. (2001) Corporate Performance Management: How to Build a Better Organization Through Measurement-Driven Strategic Alignment, ButterworthHeinemann: Woburn, MA.

Wheelen, T.L., Hunger, J.D. (2012) Strategic Management and Business Policy: Toward Global Sustainability, 13th ed, Pearson Prentice Hall: Upper Saddle River, NJ. 